Article

\title{
Friends or Foes? Rapid Determination of Dissimilar Colistin and Ciprofloxacin Antagonism of Pseudomonas aeruginosa Phages
}

\author{
Katarzyna M. Danis-Wlodarczyk ${ }^{1}$, Alice Cai ${ }^{2}$, Anna Chen ${ }^{2}$, Marissa R. Gittrich ${ }^{2} \mathbb{D}$, Matthew B. Sullivan ${ }^{2,3}$, \\ Daniel J. Wozniak ${ }^{1,2, *}$ and Stephen T. Abedon $2, *$ (D) \\ 1 Department of Microbial Infection and Immunity, The Ohio State University, Columbus, OH 43210, USA; \\ danis-wlodarczyk.1@osu.edu \\ 2 Department of Microbiology, The Ohio State University, Columbus, OH 43210, USA; \\ cai.712@buckeyemail.osu.edu (A.C.); chen.7295@osu.edu (A.C.); gittrich.1@buckeyemail.osu.edu (M.R.G.); \\ sullivan.948@osu.edu (M.B.S.) \\ 3 Department of Civil, Environmental and Geodetic Engineering, The Ohio State University, \\ Columbus, OH 43210, USA \\ * Correspondence: wozniak.1@osu.edu (D.J.W.); abedon.1@osu.edu (S.T.A.)
}

check for updates

Citation: Danis-Wlodarczyk, K.M.; Cai, A.; Chen, A.; Gittrich, M.R.;

Sullivan, M.B.; Wozniak, D.J.;

Abedon, S.T. Friends or Foes? Rapid Determination of Dissimilar Colistin and Ciprofloxacin Antagonism of Pseudomonas aeruginosa Phages. Pharmaceuticals 2021, 14, 1162. https://doi.org/10.3390/ph14111162

Academic Editor: Gill Diamond

Received: 16 October 2021

Accepted: 11 November 2021

Published: 15 November 2021

Publisher's Note: MDPI stays neutral with regard to jurisdictional claims in published maps and institutional affiliations.

Copyright: (c) 2021 by the authors. Licensee MDPI, Basel, Switzerland. This article is an open access article distributed under the terms and conditions of the Creative Commons Attribution (CC BY) license (https:/ / creativecommons.org/licenses/by/ $4.0 /)$.

\begin{abstract}
Phage therapy is a century-old technique employing viruses (phages) to treat bacterial infections, and in the clinic it is often used in combination with antibiotics. Antibiotics, however, interfere with critical bacterial metabolic activities that can be required by phages. Explicit testing of antibiotic antagonism of phage infection activities, though, is not a common feature of phage therapy studies. Here we use optical density-based 'lysis-profile' assays to assess the impact of two antibiotics, colistin and ciprofloxacin, on the bactericidal, bacteriolytic, and new-virion-production activities of three Pseudomonas aeruginosa phages. Though phages and antibiotics in combination are more potent in killing $P$. aeruginosa than either acting alone, colistin nevertheless substantially interferes with phage bacteriolytic and virion-production activities even at its minimum inhibitory concentration $(1 \times$ MIC). Ciprofloxacin, by contrast, has little anti-phage impact at $1 \times$ or $3 \times$ MIC. We corroborate these results with more traditional measures, particularly colony-forming units, plaque-forming units, and one-step growth experiments. Our results suggest that ciprofloxacin could be useful as a concurrent phage therapy co-treatment especially when phage replication is required for treatment success. Lysis-profile assays also appear to be useful, fast, and high-throughput means of assessing antibiotic antagonism of phage infection activities.
\end{abstract}

Keywords: antibacterial therapy; bacteriophage therapy; ciprofloxacin; colistin; phage PEV2; phage ФKMV; phage LUZ19

\section{Introduction}

"It's not about phages or antibiotics. It's about phages and antibiotics." Paul Grint [1].

Development of the first antibacterial chemotherapeutics, Salvarsan [2,3], Prontosil [4], and penicillin [5], transformed clinical treatments of bacterial infections. Though antibiotic therapy came to represent the standard of care for the treatment of these infections, its utility is threatened by the emergence of multi/pan-drug resistant or tolerant pathogens [6,7]. This has led to increased health care expenses and economic damages that are comparable to those of the 2008-2009 global financial crisis [8].

The U.S. Centers for Disease Control and Prevention (CDC) estimates that more than 2.8 million antibiotic-resistant infections occur each year, leading to more than 35,000 deaths only in the United States [9]. Globally, this number increases to at least 700,000 deaths each year [8] and is predicted to lead to 10 million deaths per year by 2050 [10]. This is particularly concerning given the limited number of new antimicrobial agents, both currently 
available and in drug development pipelines, that are active especially against Gramnegative pathogens [11]. Moreover, infections by even antibiotic-sensitive bacteria can lead to antibiotic tolerance [12-18]. Thus, additional antibacterial agents and approaches are needed, with traits of interest including abilities (1) to treat antibiotic-recalcitrant bacterial infections, (2) to reduce the potential for bacteria to evolve resistance, and (3) to work in conjunction with traditional, standard-of-care antibiotics.

One emerging antibacterial approach is phage therapy [19,20]. Bacteriophages (phages) can lyse and kill bacteria and collectively are the most abundant replicative entities in the biosphere [21]. They have been in common clinical use for decades in several countries, particularly those from former the Soviet Union republics (Georgia and Russia) as well as Poland. Currently, in Europe as well as in the U.S. [22-27], new phage therapy centers are opening and several new clinical trials are taking place [28-33].

Phage therapy in the clinic is often used in concurrent combination with antibiotic treatments [26,34-74]. Crucial with combination therapies, however, is avoidance of substantial antagonisms between agents $[75,76]$. Phages, while infecting antibiotic-treated bacterial populations, ideally should retain bactericidal, bacteriolytic, and virion production activities. It can be useful, therefore, to identify possible incompatibilities between specific phages and antibiotics early during the development of combination therapies, or in the course of compassionate use $[19,25,27]$. There has been comparatively little analysis, though, of the antagonistic impacts of antibiotics on the ability of phages to successfully infect and lyse antibiotic-sensitive bacteria under standard, pharmacologically relevant conditions.

When testing has been completed, emphasis instead is usually on combinations of phages and sub-inhibitory antibiotic concentrations along with their impact on the growth of bacterial cultures over multiple-hour time scales or using biofilm-based instead of brothbased assessments. We feel, therefore, that it would be a useful addition to the study of phage therapy to employ pre-clinical analyses that (1) are broth based, (2) use standard media for MIC evaluation (Mueller-Hinton broth), (3) employ standard-of-care antibiotic concentrations, i.e., minimum inhibitory concentrations (MICs) or higher, (4) take place over the time scales that are roughly equivalent to those of individual phage infections, and (5) examine especially anticipated [47] antagonistic impacts of antibiotics on phage properties relative to no-antibiotic controls.

To assess the impact of antibiotics on the antibacterial activities of phages, given the substantial numbers of combinations of therapeutic phage and antibiotic types that are possible, higher-throughput approaches are needed, and ideally these would be performed under conditions that are similar to those employed to determine antibiotic MICs [77-79]. Here, we validate a 96-well microtiter plate-compatible turbidimetric, 'lysis-profile' [80] means of assessing phage infection activity in the presence and absence of antibiotics, as corroborated by other traditional but more time-consuming methods of phage infection activity determination. This was carried out using two antibiotics possessing contrasting mechanisms of action, colistin and ciprofloxacin. We find that colistin, even at low but still bacteria-inhibiting concentrations, is highly antagonistic to the infection activities of three Pseudomonas aeruginosa phages, PEV2 [81,82], LUZ19 [83], and $\varphi$ KMV [84]. In contrast, even in the presence of relatively high but still clinically relevant concentrations of ciprofloxacin, these phages retain substantial bacteriolytic and virion-production activities.

\section{Results}

Using a rapid, semi-automated, lysis profile-based workflow (Figure 1), we assessed the impact of two antibiotics, colistin or ciprofloxacin, on P. aeruginosa phage PEV2 infection activities. We were then able to confirm phage population growth and bactericidal activities through endpoint plating of these cultures for plaque-forming units (PFUs) and colony-forming units (CFUs). Results were then evaluated separately via one-step growth experiments and using different $P$. aeruginosa phages. See Appendix A for discussion of 
colistin and ciprofloxacin MICs, clinical dosages, and pharmacology. See Appendix B for a detailed description of lysis-profile analysis.
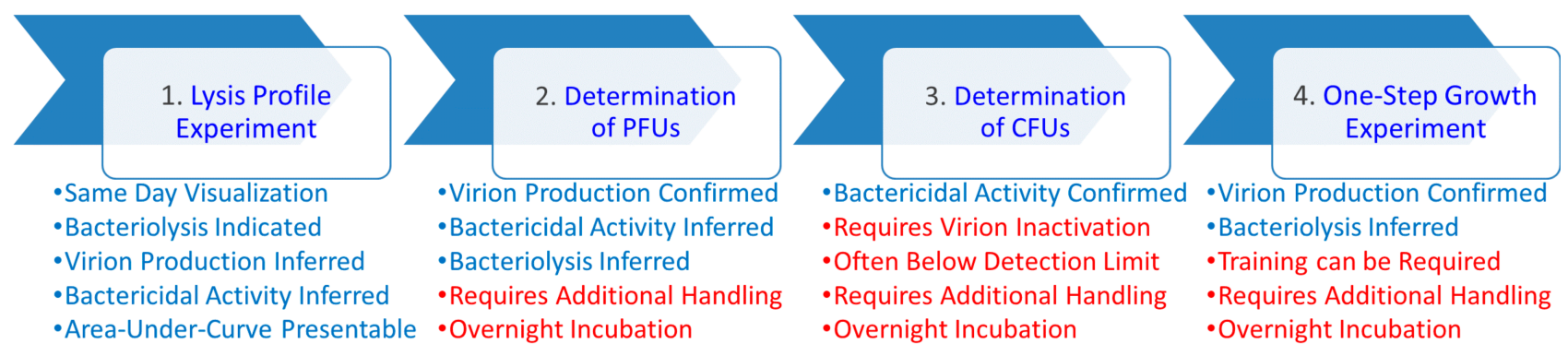

Figure 1. Workflow schematic with pros and cons of the different approaches indicated. Different analyses are indicated in bubbles (top), with pros (blue) and cons (red) of each approach presented beneath. These include: (1) Lysis profile experiments as can be performed employing a variety of phage multiplicities of infection (MOIs) and antibiotic concentrations (multiples of MICs). Immediately following individual lysis profile experiments, both (2) PFU (plaque-forming unit) and (3) CFU (colony-forming unit) determinations can be undertaken to confirm virion production activities as well as bactericidal impacts, with these latter analyses requiring both plating and overnight incubation. (4) Phage infection activities can then be corroborated using separate one-step growth experiments. "Requires additional handling" refers to, e.g., diluting and plating of cultures along with counting of plaques or colonies. "Training can be required" refers to the greater technical difficulty associated with performing one-step growth experiments relative to lysis-profile, PFU, or CFU determinations. Bactericidal activity is the physiological killing of bacteria, as can be assessed as reductions in colony-forming units (CFUs). In practice, such as following certain antibiotic treatments, this can occur without bacterial lysis. Bacteriolytic activity involves the physical destruction of bacterial cell envelopes as can be observed as drops in bacterial culture turbidity, but which will result in reductions in CFU counts as well. Virion production is assessed as increases in numbers of plaque-forming units (PFUs), which for lytic phages also will be associated with bacterial lysis as well as bacteria killing. See Appendix B for an explanation of how the occurrence of virion production also may be inferred from lysis profile curves.

\subsection{Colistin: High Levels of Anti-Phage Antagonism}

Colistin (polymyxin class) is a rapid-acting bactericidal antibiotic that disrupts the bacterial outer membrane, leading to leakage of cell contents and bacterial death [85]. This action is achieved partially by colistin displacing the calcium and magnesium bridges that stabilize lipopolysaccharide (LPS) [86-90]. In our study, phage PEV2 lysis profiles in the presence of colistin at $1 \times$ MIC showed only limited but nevertheless still clearly detectable phage-associated bacteriolytic activity, as seen with the MOI 5 and 10 curves (Figure 2C and see also Appendix B). No phage-associated bacteriolytic activity appears to occur, however, at higher colistin concentrations (Figure 2D,E). The MOI 0.1 and 1 curves at $1 \times$ MIC showed little or no difference relative to no phage addition, suggesting little virion production activity together with low phage-associated bacteriolytic activity (both as seen in Figure 2C). These results are summarized in Figure 2F,G in terms of area under the curves (AUCs) and as heat maps based on $\log _{10}(\mathrm{AUC})$ calculations (Figure S1A).

Phage PEV2 (family Podoviridae) utilizes LPS as its surface receptor (Table S1). This could be a contributor to the observed antagonism of this phage's infection activity by colistin, as LPS is directly disrupted by that antibiotic. Similar anti-phage antagonism was observed, however, with the infection activity of other P. aeruginosa phages, Autographiviridae family phages LUZ19 and $\Phi K M V$, that utilize instead type IV pili as their surface receptor (Table S1 and Figures S2 and S3). In adsorption experiments, we did observe phage virionattachment antagonism in the presence of colistin, even at low concentration $(1 \times \mathrm{MIC})$, though not to a sufficient degree to indicate a blockage of phage PEV2 nor phage LUZ19 infection abilities, e.g., less than one-half reductions in adsorption rate constants. Though these results are suggestive of a general trend of phage infection activity antagonism by colistin, they are not indicative of the specific cause of that antagonism. We also confirmed [91] that neither colistin nor ciprofloxacin impact virion stability (Figure S5). 

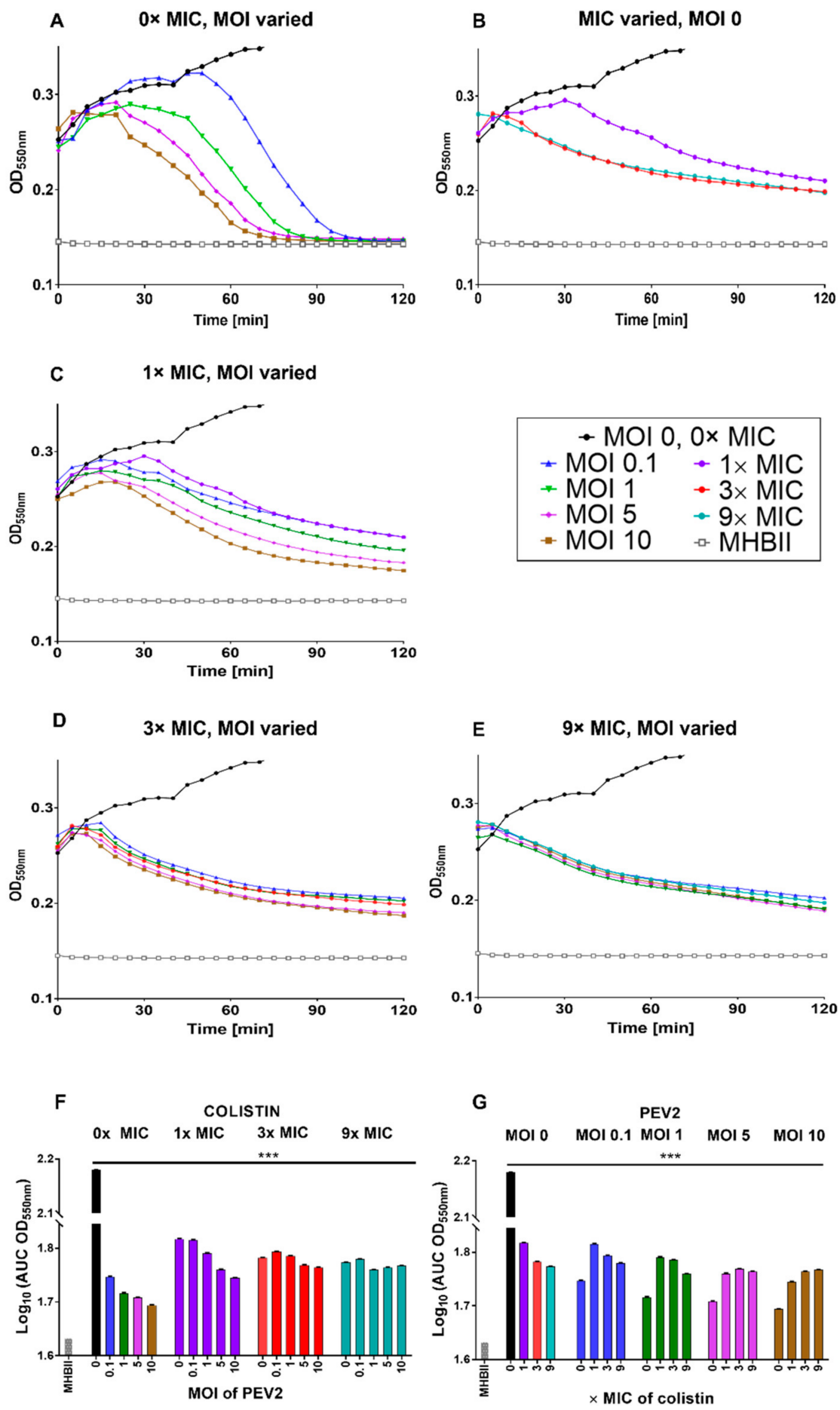

Figure 2. Colistin strongly antagonizes phage PEV2 infection of P. aeruginosa. (A) Phage PEV2 behavior in the absence of colistin and impact on P. aeruginosa PAO1 cultures. (B) Impact of different concentrations of colistin on P. aeruginosa PAO1 culture without phage. (C-E) Impacts of $1 \times, 3 \times$, and $9 \times$ MIC concentrations of colistin, respectively, at various MOIs of phage PEV2 including no-phage, colistin-only controls. $(\mathbf{F}, \mathrm{G})$ Area under the curve analysis of PEV2 infection with colistin as derived from lysis profile experiments equivalent to those presented in (A-E). The smaller the area under a lysis profile curve then the greater the reductions in culture turbidity over time, such as mediated by phage infection. A key is provided in the black frame. Error bars represent standard deviation between samples. See Appendix A for description of the explicit colistin concentrations used and Appendix B for interpretation of lysis profile results. A single representative experiment is shown. $[* * *] p<0.0005$, ANOVA. 


\subsection{Ciprofloxacin: Low Levels of Anti-Phage Antagonism}

Ciprofloxacin, a fluoroquinolone class antibiotic, binds to DNA gyrase (topoisomerase II) or topoisomerase IV in the presence of DNA [92] and prevents the unlinking or decatenation of DNA following its replication while also negatively impacting positive supercoil relaxation and torsional stress relief ahead of transcription and replication complexes $[93,94]$. Representative lysis profile experiments illustrating the impact of ciprofloxacin on phage PEV2 infection are presented in Figure 3. Contrasting the colistin results (Figure 2), negative impacts on lysis-profile kinetics are minimal at $1 \times$ and $3 \times$ MIC ciprofloxacin (compare Figure $3 \mathrm{~A}, \mathrm{C}, \mathrm{D})$. At $9 \times \mathrm{MIC}$, which is slightly above the maximum serum concentration associated with a $500 \mathrm{mg}$ ciprofloxacin dose in the clinic (Appendix A), bacteriolytic activity also is relatively unchanged, as seen at MOIs of 1, 5, and 10 (Figure 3E). With MOI 0.1 and $9 \times$ MIC, however, culture-wide lysis is delayed (Figure $3 \mathrm{~F}$ ), suggesting reduced burst sizes at that ciprofloxacin concentration. See Appendix B for a discussion of these inferences.

At $27 \times$ and $81 \times$ MIC $(8.24 \mu \mathrm{g} / \mathrm{mL}$ and $24.72 \mu \mathrm{g} / \mathrm{mL}$, respectively), which are well above maximum serum concentration of the highest ciprofloxacin clinical dose (1000 mg, $5.4 \mu \mathrm{g} / \mathrm{mL}$ maximum serum concentration, see Appendix A), some phage bacteriolytic activity might still persist (Figure $3 \mathrm{~F}, \mathrm{G}$ ), and perhaps even some virion production (at $27 \times$ MIC only). See Figure $3 \mathrm{H}$,I for a summary of ciprofloxacin results in terms of AUCs and Figure S1B for heat map based on $\log _{10}(\mathrm{AUC})$ calculations. Similar results were obtained for phage LUZ19 and ФKMV (Figures S6 and S7). We also found no difference in any of these results when phage addition was not concurrent with antibiotic addition but instead delayed by $30 \mathrm{~min}$, suggesting that the relatively low antagonistic impact of ciprofloxacin on phage infection activity is not a consequence of delays in the initiation of ciprofloxacin activity (data not presented).

In adsorption experiments, ciprofloxacin, in contrast to colistin, had no negative impact on phage adsorption rates even at high concentrations $(81 \times$ MIC) (Figure S4).

\subsection{Plaque-Forming Unit Counts Support Lysis Profile Results}

While virion production is expected during infections of bacteria by strictly lytic phages, it is not a given that this will occur in the presence of antibiotics. Therefore, at the completion of lysis profile-type experiments (Figures 2 and 3), we directly assessed endpoint phage viable counts (PFU).

Consistent with lysis-profile results (Figure 2), endpoint PFU counts are substantially decreased at $1 \times$ MIC colistin in comparison to the no-antibiotic control (over two-log reductions for MOI 0.1, $p<0.05$ ), and reduced below input PFUs at $3 \times$ MIC or greater $(p<0.005$, Figure $4 \mathrm{~A})$. Also consistent with the lysis profile results, ciprofloxacin at $1 \times$ and $3 \times$ MIC only minimally decreased phage PEV2 PFUs at all MOIs relative to the no-ciprofloxacin control ( $p<0.05$, Figure $4 \mathrm{~B})$. Ciprofloxacin concentrations of $9 \times \mathrm{MIC}$, however, reduced phage PEV2 PFU counts by $\sim 1$ log at all MOIs tested $(p<0.05)$ relative to the no-ciprofloxacin control and these levels were not significantly different from input PFUs with MOI 10 (Figure 4B). At ciprofloxacin concentrations of $27 \times$ and $81 \times$ MIC, which are above maximum serum concentration of the highest clinical ciprofloxacin dose (Appendix A), drops in phage titers were observed in comparison to input concentrations of phage PEV2 for MOIs 1 through $10(p<0.05)$, but with no change for $27 \times$ MIC and MOI 0.1 . Together these results are suggestive that PFU determinations can serve as facile means of corroborating lysis-profile results, though at a cost of additional time and effort relative to performing lysis-profile experiments alone. 

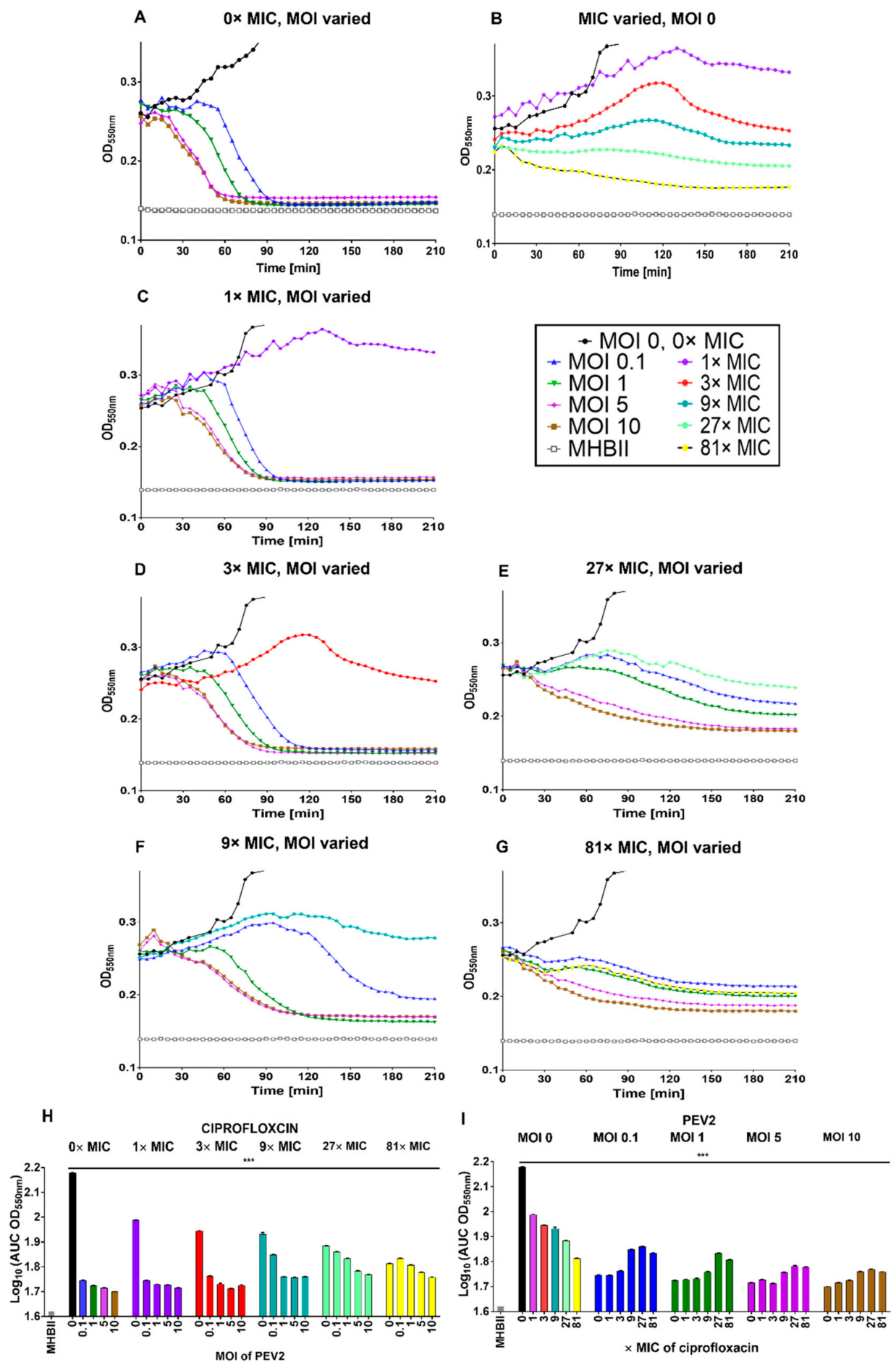

Figure 3. Ciprofloxacin low antagonism of phage PEV2 infection of P. aeruginosa. (A) Phage PEV2 behavior in the absence of ciprofloxacin and impact on P. aeruginosa PAO1 cultures. (B) Impact of different concentrations of ciprofloxacin on P. aeruginosa PAO1 cultures without phage. (C-G) Impacts of $1 \times, 3 \times, 9 \times, 27 \times$ and $81 \times$ MIC concentrations of ciprofloxacin, respectively, at various phage PEV2 MOIs including no-phage ciprofloxacin controls. $(\mathbf{H}, \mathbf{I})$ Area under the curve analysis of PEV2 infection with ciprofloxacin as derived from lysis-profile experiments equivalent to those presented in (A-G). A key is provided in the black frame. Error bars represent standard deviation between samples. See Appendix A for explicit ciprofloxacin concentrations used and Appendix B for interpretation of lysis profile results. A single representative experiment is shown. $\left.{ }^{* * *}\right] p<0.0005$, ANOVA. These experiments are indicated in this figure over a longer time scale than that used in Figure 2 due to the greater variation between curves seen later in infections with ciprofloxacin vs. colistin treatments. 

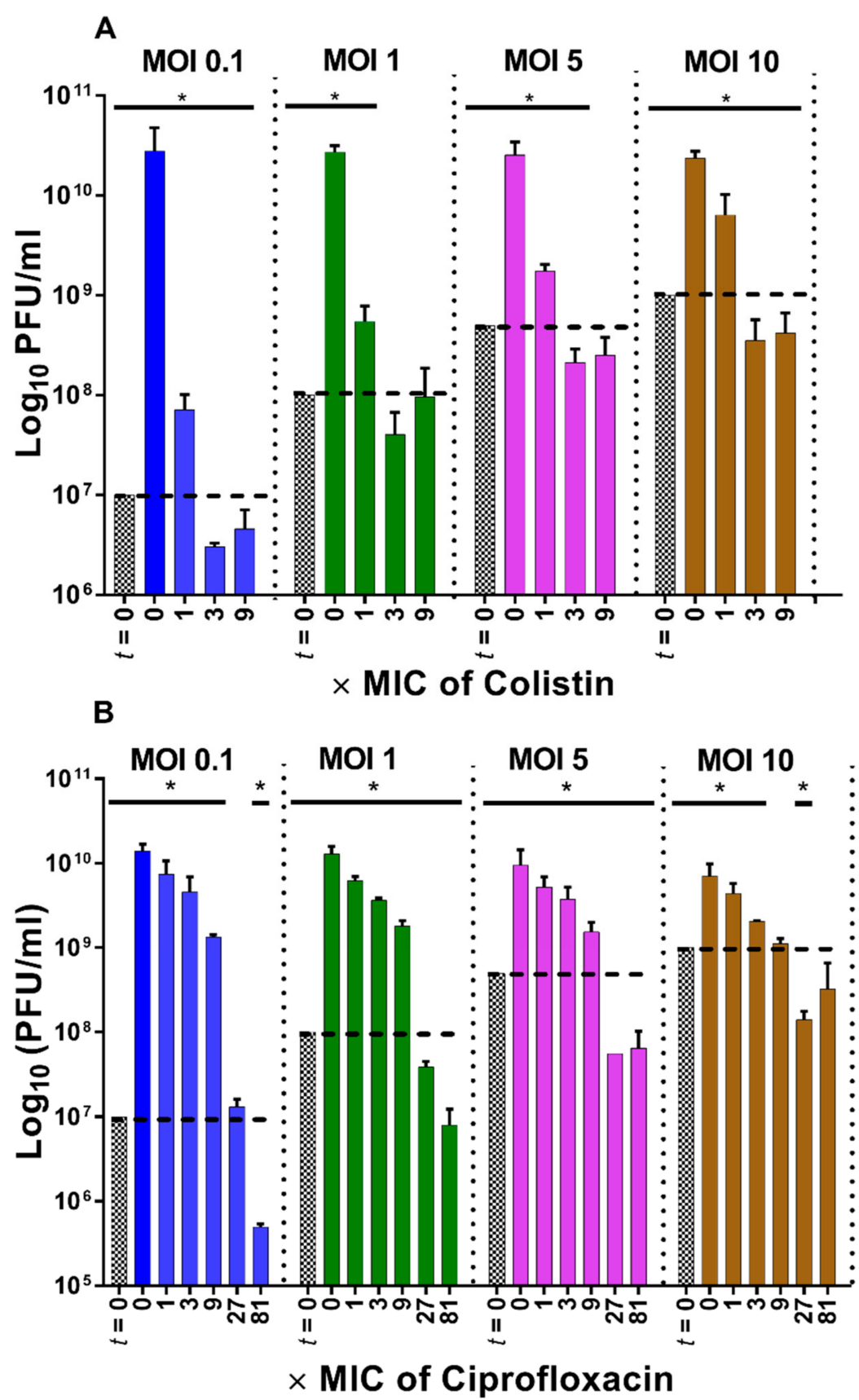

Figure 4. Corroboration of high antagonism of colistin and lower antagonism of ciprofloxacin on phage PEV2 production. Following lysis-profile experiments, counts of phage plaque-forming units (PFUs) were determined in the absence or presence of colistin (A) and ciprofloxacin (B) treatments (different MICs, see bottoms of graphs) and with different starting MOIs (tops of graphs). PFUs above the dashed lines indicate more phages present than at the start of experiments. Patterned bars $(t=0)$ represent phage titers applied at the beginning of experiments and are compared with $5 \mathrm{~h}$ time points (a sampled from cultures immediately following lysis-profile determinations). $\left[{ }^{*}\right] p<0.05$, ANOVA when compared to initial (input) titer $(t=0)$.

\subsection{Colony-Forming Unit Reductions in the Presence of Phages and Antibiotics}

Decreases in numbers of CFUs relative to the start of lysis-profile experiments are directly indicative of treatment bactericidal activities. Phage PEV2 reduced CFU counts over the $5 \mathrm{~h}$ incubation by at least $99.999 \%(4 \mathrm{log})$ in all single (phage-only) and mixed treatments (phage plus antibiotic; $p<0.005$ ) (Figure 5). Colistin treatment alone at $1 \times$ MIC reduced CFUs over one log more than all phage-only treatments $(p<0.005)$, i.e., about 
5 logs. Combination treatments of colistin (for all MICs) and phage PEV2 (for all MOIs) as well as colistin alone, at $3 \times$ MIC and greater, were the most successful at reducing CFU counts, by a total of at least 6 logs. There was no significant difference between all phage treatments alone (MOIs 0.1 through 10) and ciprofloxacin treatment alone at $1 \times$ MIC. At $3 \times$ MIC, ciprofloxacin alone reduced CFU numbers to a greater extent (over 1 log more, $p<0.05)$ than phage-alone treatments. As also in the case of colistin, co-treatment with phages (all MOIs) and ciprofloxacin (all MICs) were the most successful at reducing CFU counts ( $\geq 6 \log$ reduction).
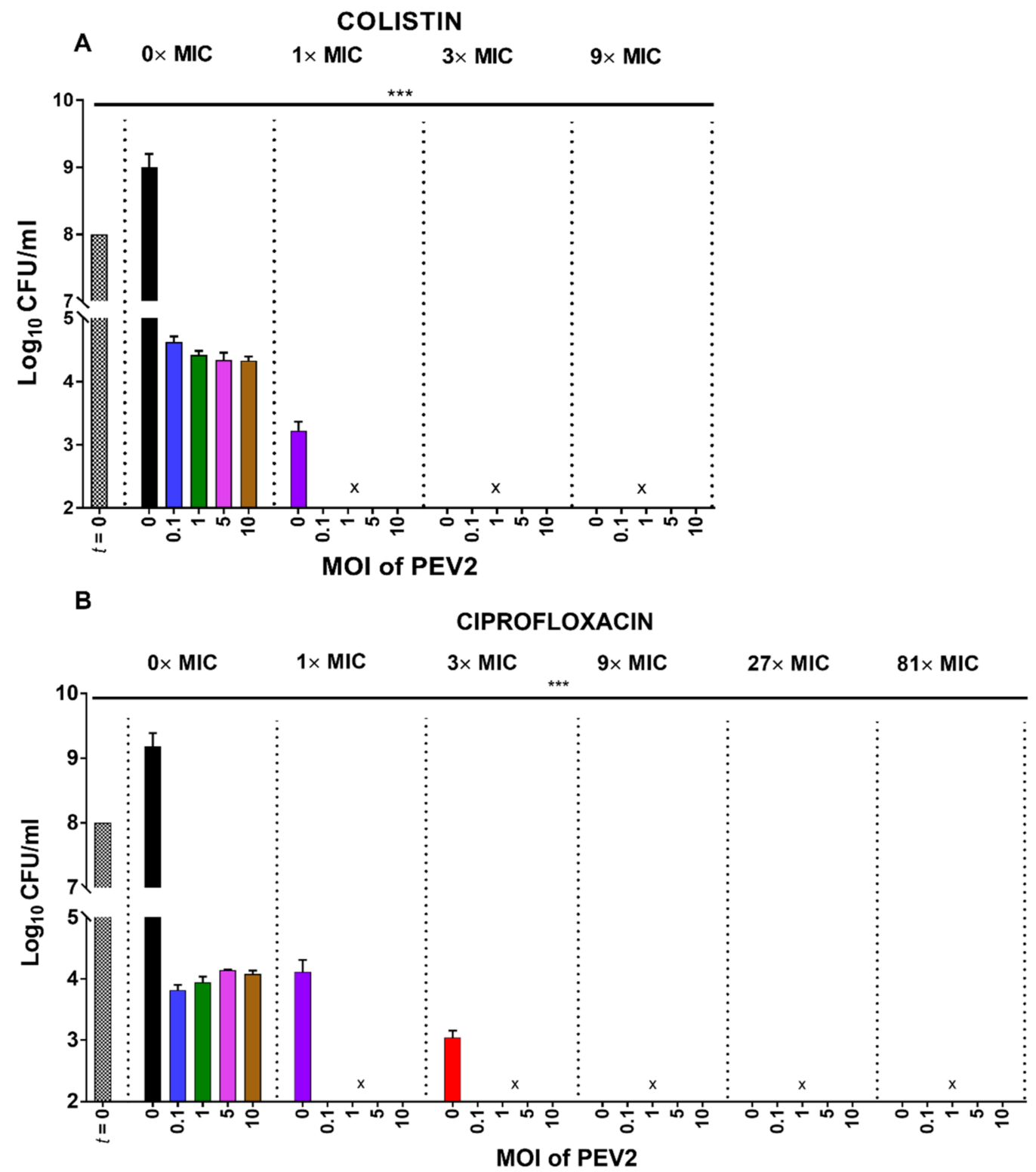

Figure 5. Higher impact of phage-antibiotic combination treatments. Following lysis-profile experiments, counts of bacterial colony-forming units (CFUs) were determined with and without phage treatments (different MOIs, see bottoms of graphs), with and without antibiotic treatments, colistin (A) vs. ciprofloxacin (B) (different MICs, see tops of graphs), and combined treatments. To prevent bactericidal phage adsorption during enumeration, CFU analyses were performed in the presence of free phage-inactivating virucide consisting of $7.5 \%$ black tea infusion and $0.53 \% \mathrm{FeSO}_{4}$ [95]. [***] $p<0.005$, ANOVA. [x] represent results below detection limit of this assay $\left(10^{2} \mathrm{CFUs} / \mathrm{mL}\right)$.

Notwithstanding these substantial reductions in CFUs, both with and without phages or antibiotics present (Figure 5), these results do not appear to supply much of a means of distinguishing the impact of colistin vs. ciprofloxacin on phage PEV2 infection activity, 
and this likely is mostly due to the impact of antibiotic treatment alone reducing CFUs to near or below detection limits. The Figure 5 results, however, are still broadly consistent with those found in Figure 4 in terms of PFU increases. Specifically, in the presence of $1 \times$ MIC for both colistin and ciprofloxacin, and $3 \times$ MIC for ciprofloxacin, phages were still able to increase in number from nearly to well over 1 log over the course of lysis-profile experiments (Figure 4). At those same MICs, phages reduced CFUs beyond what was attained by antibiotics alone, no matter the starting MOI (Figure 5). This means that even with a starting MOI of 0.1, and certainly with higher starting MOIs, the number of phages present at the end of lysis-profile experiments (Figure 4) should have been sufficient to result in an observable reduction in CFUs relative to antibiotic treatment alone, as indeed was observed (Figure 5). Especially, a final titer of nearly $10^{8} \mathrm{PFU} / \mathrm{mL}$, which is the minimum number of phages in the presence of those MICs, should easily result in a 1-log reduction in bacterial numbers over the course of experiments. Overall, we find that PFU determinations (Figure 5) may provide a better indication especially of low levels of phage replication in the presence of antibiotics than lysis-profile determinations alone (compare Figure 5A with Figure 2C). Furthermore, endpoint $\mathrm{CFU}$ determinations alone, as performed here, seem to only be confirmatory that phages along with bactericidal antibiotics are able to kill bacteria.

\subsection{One-Step Growth Experiments Corroborate Lysis Profile Results}

For $\sim 80$ years the standard method of assessing phage infection characteristics, particularly determining phage burst sizes and latent period lengths, has been using one-step growth experiments [96-98]. These differ from lysis profiles both in terms of the potential for lysis-released virions to adsorb already phage infected bacteria (high potential with lysis profiles vs. low potential with one-step growth experiments) and the means of detection of phage infection activities (culture turbidity for lysis profiles vs. plaque counts for one-step growth experiments). Importantly, however, one-step growth analysis can be much more complicated and time-consuming (e.g., weeks for optimization to specific phages, bacteria, and conditions) and are not easily automated. The lysis-profile analyses presented here, i.e., Figures 2 and 3, by contrast, involve little optimization, require only a few hours to set up and run, use standard incubating and shaking microtiter plate reading machines, and like other phage assays based on optical density readings [99], can be performed with high throughput.

Given the importance of one-step growth analysis as the standard means of assessing phage infection activities, we have employed it to test the accuracy of the presented lysis profiles (Figures 2 and 3 ) as predictors of these same activities. In the absence of antibiotics, we found that the phage PEV2 latent period lasts $\sim 18 \mathrm{~min}$, resulting in a burst size of $135 \pm 5.6$ new virions. This timing of lysis seems to correspond, as expected, more or less to the MOI 5 and 10 lysis profiles shown in Figures 2A and 3A.

At $1 \times$ and $3 \times$ MIC, colistin did not have a significant impact on the phage PEV2 latent period length (Figure $6 \mathrm{~A}$ ), a result that was not detectable in our lysis profile assays (Figure 2C,D). At higher colistin concentrations $(>3 \times \mathrm{MIC})$, lawn growth during PFU assessment was inhibited, presumably by antibiotic carry over, and therefore one-step growth assessment could not be performed. Contrasting the consistency of latent periods seen in the presence of $1 \times$ and $3 \times$ MIC colistin, burst sizes were substantially reduced $(p<0.005$ ), to $9.6 \pm 0.57$ (reduction of $92.9 \%$ ) and $2.5 \pm 0.2$ (reduction of $98.1 \%$ ), respectively, given phage infection exposure to these concentrations of colistin (Figure 6B,C). 
A

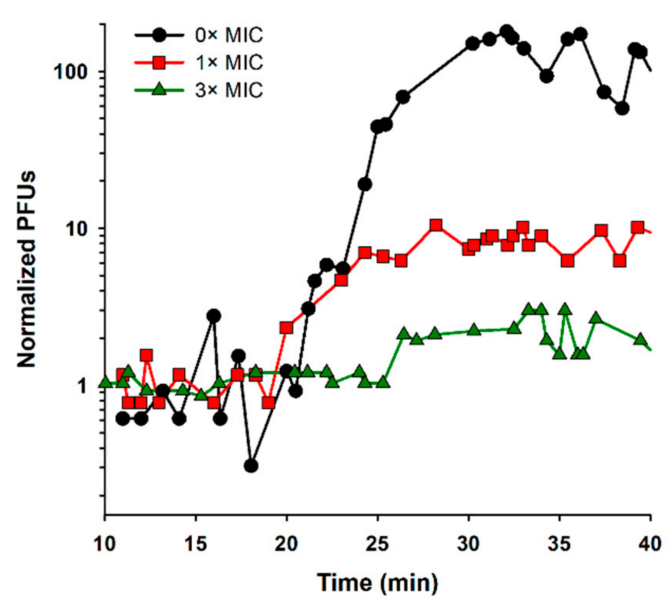

B

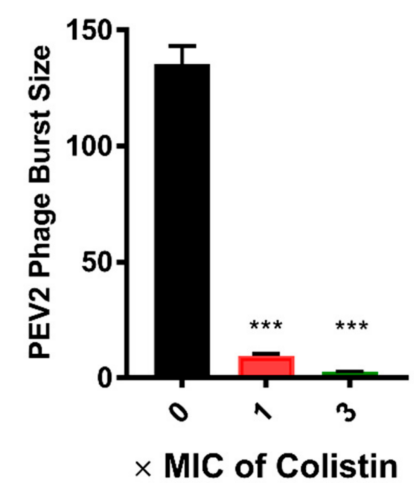

C

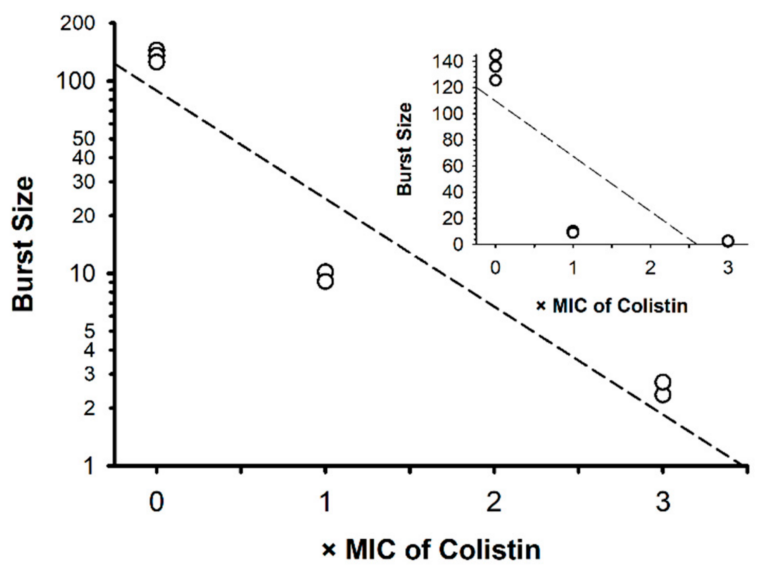

D

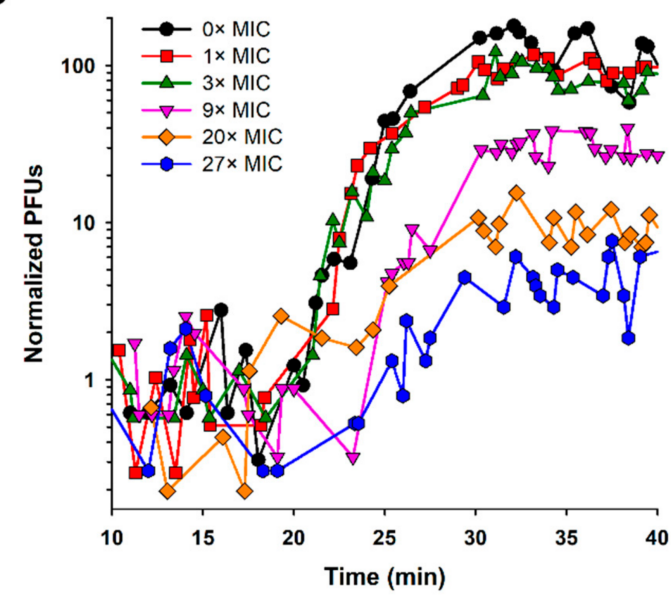

E

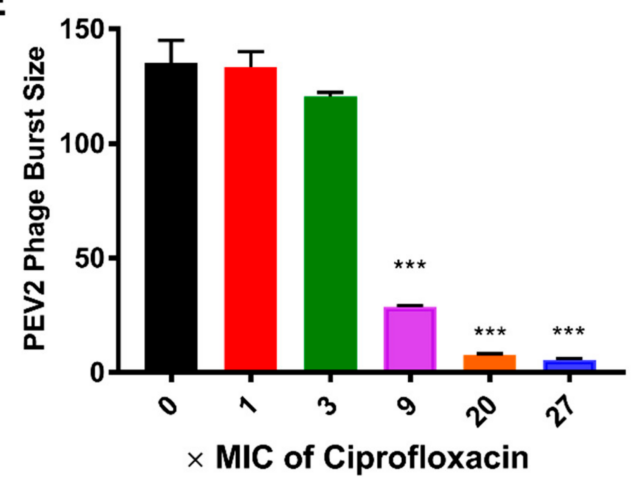

F

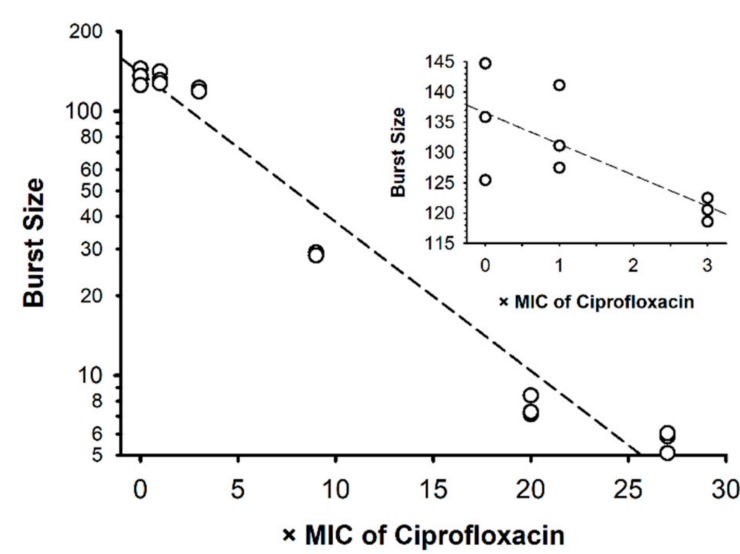

Figure 6. PEV2 one-step infection cycle characteristics in the absence or presence of antibiotic. Shown are one-step growth curves of phage PEV2 infection (MOI 0.05) in the absence or presence of either colistin (A) or ciprofloxacin (D), in both cases with numbers of PFUs normalized so that the average initial numbers of phage-infected bacteria for all curves are set to 1.0. Graphed in the second row are phage PEV2 burst sizes determined in the absence or presence of different colistin (B) or ciprofloxacin (E) concentrations. Error bars represent standard deviations between three experiments (biological repeats). Shown in the bottom row is the relationship between burst size and either colistin (panel $(\mathrm{C}), \mathrm{m}=-0.561, \mathrm{r}=0.938$ ) or ciprofloxacin (panel $(\mathbf{F}), \mathrm{m}=-0.056, \mathrm{r}=0.982$ ) concentrations. Inserts show burst sizes using linear scales at the first three concentrations $(0 \times, 1 \times$, and $3 \times$ MIC). Mean values of burst size are calculated based on 3 separate experiments. The dotted line represents a trend line. $\left.{ }^{* * *}\right] p<0.005$, ANOVA, $(\mathrm{r})$ linear regression, $(\mathrm{m})$ slope. See Appendix A for detailed antibiotics concentrations. 
The phage PEV2 latent period length did not change with $1 \times$ or $3 \times$ MICs but was delayed at $9 \times$ MIC and higher of ciprofloxacin, as mirrored by the MOI 5 and 10 lysis profile results presented in Figure 3. Burst sizes were $133.2 \pm 4.1,120.5 \pm 1.1,28.8 \pm 0.3$ phage PFUs per infected bacterial cell, corresponding to $1.5 \%, 10.9 \%$ and $78.7 \%$ reductions, respectively (Figure 6E,F). When ciprofloxacin concentrations were increased to $20 \times$ and $27 \times \mathrm{MIC}$, the phage PEV2 latent period was postponed by $\sim 3$ and $\sim 7 \mathrm{~min}$, respectively (Figure 6D), and burst sizes dropped to $7.6 \pm 0.4$ and $5.7 \pm 0.3$ phages/infected bacterium (Figure $6 \mathrm{E}, \mathrm{F}$ ), the latter corresponding to reductions of $94.4 \%$ and $95.8 \%$. Burst size changes during lysis profiles should be most detectable with MOI 0.1 curves and seen as delays in optical density reductions as phage populations more slowly grow to multiplicities in excess of 1, particularly as bacterial numbers grow as well due to binary fission prior to their becoming phage infected. Such a delay in culture-wide lysis with MOI 0.1 is most obviously seen with $9 \times$ MIC ciprofloxacin in Figure $3 \mathrm{~F}$.

In Figure 6C,F, the rate of decline of phage PEV2 burst sizes as functions of colistin and ciprofloxacin concentrations are indicated. Based on the calculated slopes of the log-linear graphs (main graphs, not insets), we can conclude that increasing colistin concentrations reduce the phage PEV2 burst size at a rate that is ten-fold greater than the corresponding ciprofloxacin antagonistic impact in terms of MICs: $(m=-0.561) /(m=-0.056)=10$.

These one-step growth results are consistent with the lysis profile and PFU results presented in Figures 2-4, indicating for example that ciprofloxacin does not excessively interfere with phage infection activities until relatively high antibiotic concentrations $(>9 \times$ MIC) vs. colistin which substantially interferes with these phage activities even at relatively low concentrations $(1 \times \mathrm{MIC})$. Both bacteriolysis and virion production seem to not be completely interfered with during lysis profiles at $27 \times \mathrm{MIC}$ of ciprofloxacin (Figure 3E, MOIs 5 or 10, and Figure 4B, MOI 0.1, respectively) nor bacteriolysis with $1 \times$ MIC of colistin (Figure $2 \mathrm{C}$ ), though both are at or nearing the limits of detection in each case. These results would appear to be consistent with the observed retention in one-step growth experiments of low but still present burst sizes in the presence of those concentrations of the respective antibiotics.

\section{Discussion}

In combination therapies, two or more agents possessing different mechanisms of action can enhance each other's activities [100-102], broaden activity spectra [101,103-105], reduce the potential for resistance evolution [106-113], and improve penetration into biofilms [114]. They can, however, also be antagonistic to each other's functioning [16,17,115]. Antibiotics, for example, are known to be potentially antagonistic to phage infection activities [47]. One common aspect of both pre-clinical [34,42,47,102,114,116-122] and clinical phage therapy treatments [26,34-74], however, is concurrent combination of phages with antibiotics. Here we have assessed the potential of two different antibiotics, colistin (polymyxin) and ciprofloxacin (fluoroquinolone), to interfere with the infection activities of P. aeruginosa phage PEV2, LUZ19, and $\Phi$ KMV at bacterial growth-inhibiting antibiotic concentrations (greater than or equal to MIC). We found that colistin was far more antagonistic than ciprofloxacin, with a ten-fold greater rate of reduction in burst size seen as a function of increasing colistin concentrations vs. increasing ciprofloxacin concentrations.

As follows, we consider the extent to which antagonistic impacts on phage infection activities stemming from the action of these two antibiotics have been observed in other studies. We note as a general comment, however, that it is possible for many studies that MIC determinations and phage experiments were conducted using different media, perhaps resulting in different actual MICs under experimental conditions from those reported. We therefore have indicated what media phage experiments were performed in along with MIC determinations, which we assume as a default were likely performed using Mueller-Hinton media. By contrast, all experiments presented in the current study were conducted using exclusively Mueller-Hinton Broth, cation-adjusted. 


\subsection{High Antagonistic Impact of Colistin}

In this section, we consider studies that have explored the impact of colistin on the infection activity of various phages. David et al. [91], for instance, showed that colistin at $1 \times$ MIC $(1 \mu \mathrm{g} / \mathrm{mL})$ inhibited phage production during infection of Mycobacterium aurum in heart-infusion broth. Often, though, this information must be inferred rather than having been measured directly, including whether or not antibiotic concentrations used were sufficient to inhibit bacterial growth or metabolism. Jansen et al. [42], for example, reported phage-mediated reductions of Acinetobacter baumannii culture growth in lysogeny broth in the presence of $1 \times$ and $4 \times$ MIC colistin $(0.5$ to $8 \mathrm{mg} / \mathrm{L}$ ), though not at $2 \times$ MIC colistin. They also observed, however, little reduction in culture growth in the presence of these concentrations of colistin alone.

Using a cocktail of two phages, Chaudhry et al. [102] similarly observed substantial phage population growth as well as phage-associated reductions in P. aeruginosa PA14 (vs. PAO1 as used here) with $8 \times$ MIC $(20 \mu \mathrm{g} / \mathrm{mL})$ colistin suspended in lysogeny broth. In these experiments, however, phages were targeting bacterial biofilms rather than planktonic bacteria, and biofilms tend to be more tolerant of colistin than bacteria found in broth [123]. MICs do not appear to have been determined in this study using biofilm-grown bacteria, however, and neither $1 \times$ nor $8 \times$ MIC colistin alone had much negative impact on so-treated biofilms. With similar caveats, Danis-Wlodarczyk et al. [124] observed in tryptic-soy broth that application of the giant phiKZvirus KTN4 (P. aeruginosa phage), together with $100 \mu \mathrm{M}$ $(116 \mu \mathrm{g} / \mathrm{mL})$ of colistin, substantially reduced a P. aeruginosa PAO1 $72 \mathrm{~h}$ old biofilm, while colistin alone did not have an impact and phage-alone treatment reduced biofilm to a lesser extent than the combination treatment. The phage, however, was not more effective than colistin alone against $24 \mathrm{~h}$ or $48 \mathrm{~h}$ biofilm. MIC was not determined, but the colistin concentration used was found to reduce the growth of $24 \mathrm{~h}$ biofilm, leaving open a possibility that it was less effective against the $72 \mathrm{~h}$ biofilm.

Overall, then, evidence of substantial phage replication while infecting bacteria that are truly colistin-inhibited in their growth is not robust. Carried out under conditions resembling those employed for MIC determinations (MHB), we have found that colistin is strongly antagonistic toward phage PEV2 bacteriolytic and virion production activities, e.g., with greater than $90 \%$ reduction in burst size at $1 \times$ MIC.

\subsection{Low Antagonism of Ciprofloxacin}

Consistent with our in vitro findings is the in vivo study by Oechslin et al. [125]. They found synergistic impacts of ciprofloxacin and a phage cocktail on experimental $P$. aeruginosa endocarditis in rats. This is notable since ciprofloxacin alone, at the same dosage, displayed substantial antibacterial activities in this in vivo system and thus presumably exceeded MIC there. Using a tryptic soy broth model, Oechslin et al. also found that numbers of $P$. aeruginosa cells were substantially reduced $(\sim 6 \mathrm{logs})$ after $6 \mathrm{~h}$ of exposure to concurrent co-treatments of a phage cocktail (MOI 1, $10^{8} \mathrm{PFUs} / \mathrm{mL}$ ) and ciprofloxacin $(2.5 \times \mathrm{MIC}, 0.475 \mu \mathrm{g} / \mathrm{mL})$ as well as by phage-only treatment, versus only an inhibition of bacterial growth when treated with ciprofloxacin alone. This result is suggestive of phage virion production in both the presence and absence of $2.5 \times$ MIC ciprofloxacin since the starting MOI of 1 alone at best should kill only $63 \%$ of the bacteria present [126], though we are uncertain how MIC was determined in this study.

Here, of course, we have also shown that phage infection activities can persist even at substantially higher multiples of ciprofloxacin MIC, with persistence of phage production activity at even ten times $2.5 \times$ MIC and under conditions that better match those of standard, broth-based MIC determinations. Otherwise, we have found it difficult to find evidence from the literature that phage replication can occur in the presence of truly inhibitory concentrations of ciprofloxacin. To clarify the latter point, see Appendix $C$ where we review this literature. 


\subsection{Conclusions}

Unlike most other studies that have found some compatibility between ciprofloxacin and phage treatments, here we measured antagonism under conditions that are equivalent to determinations of MICs, including the use of planktonic bacteria and Mueller-Hinton broth. We found that ciprofloxacin could be well suited for concurrent antibiotic-phage therapy co-treatment vs. colistin. This assertion is based on phage PEV2 displaying substantial bactericidal, bacteriolytic, and phage production activities even at clinically high levels ciprofloxacin, as corroborated with phages $\Phi K M V$ and LUZ19, though it will be important to test in the future additional phages for this property before progressing, e.g., to animal studies. It is striking, though, that explorations of antagonism of phage infection activity is rarely attempted before progressing even into the clinic as we have found that roughly two-thirds of clinical phage therapy studies published since 2000 employ concurrent phage-antibiotic combination therapies. Methodologically, we thus advance lysis profiles as a rapid and inexpensive broth-based assay for screening for antibiotic antagonistic impacts on phage infection activities given consistency between observations made using lysis profiles and standard one-step growth assays.

\section{Materials and Methods}

\subsection{Bacteria, Antibiotics, and Phages}

P. aeruginosa PAO1 Krylov is used as a reference strain in this study, as provided by Jean-Paul Pirnay (Queen Astrid Military Hospital, Brussels, Belgium). P. aeruginosa surface mutants used for phage receptor analysis are described in Table S1 and are isogenic to the P. aeruginosa PAO1 strain from Harvard University. Mueller-Hinton Broth II (MHB), cationadjusted (Becton Dickinson, NJ, USA), is used for bacteria liquid cultures, supplemented where indicated with different concentrations of ciprofloxacin (ciprofloxacin hydrochloride, usp reference standard, USA) or colistin (colistin sulfate, usp reference standard, USA). Minimal inhibitory concentrations (MICs) were measured by exposing a broth bacterial culture to increasing concentrations of antibiotic in $\mathrm{MHB}$, as previously described [115]. MIC for ciprofloxacin was determined as $0.91 \mu \mathrm{M}=303.2 \mathrm{ng} / \mathrm{mL}$, and for colistin MIC was found to be $39.06 \mu \mathrm{M}=68.75 \mu \mathrm{g} / \mathrm{mL}$ (see Appendix A for further discussion). Antibiotic concentrations in basic experiments were varied as $0 \times$ (no antibiotic), $1 \times, 3 \times, 9 \times, 27 \times$, and $81 \times$ MIC $(\times=$ times). Additional antibiotic concentrations were tested for ciprofloxacin between $9 \times$ and $27 \times$ MIC toward ascertaining maximal antibiotic concentrations that will still allow for phage bacteriolytic and virion production activities. We also confirmed that P. aeruginosa PA01 failed to replicate at $1 \times$ MIC colistin and ciprofloxacin using microscopic total count determinations (data not shown).

P. aeruginosa phage PEV2 (NC_031063.1, family Podoviridae, subfamily Sepvirinae, genus Litunavirus) was kindly provided by Elizabeth Kutter (Evergreen State College, Olympia, WA, USA). P. aeruginosa phages LUZ19 (NC_010326.1) and ФKMV (NC_005045.1) (family Autographiviridae, subfamily Krylovirinae, genus Phikmvoirus) were kindly provided by Rob Lavigne (KU Leuven, Leuven, Belgium). Phages were propagated in LB (Lysogeny Broth, Fisher Scientific, Hampton, NH, USA), purified via PEG precipitation ( $25 \%$ polyethylene glycol 8000, VWR, Radnor, PA, USA), subsequently suspended in phage buffer (10 mM Tris- $\mathrm{HCl}$, Sigma, $10 \mathrm{mM} \mathrm{MgSO}_{4}, 150 \mathrm{mM} \mathrm{NaCl}, \mathrm{pH} 7.5$, Fisher Scientific), and stored at $4{ }^{\circ} \mathrm{C}$, as previously described [127]. Phage titers were assessed using the double-agar layer method $[128,129]$ and defined as plaque-forming units per $\mathrm{ml}(\mathrm{PFU} / \mathrm{mL})$.

Bacterial densities were estimated as colony-forming units per $\mathrm{ml}(\mathrm{CFU} / \mathrm{mL})$. When CFUs were determined under experimental conditions, e.g., as in the presence of phages, cultures were first exposed, prior to plating, to virucide consisting of $7.5 \%$ black tea infusion (Ceylon tea from Sri Lanka, Ahmad Tea, UK) and $0.53 \% \mathrm{FeSO}_{4}$ (Sigma, Germany), prepared according to the Chibeu and Balamurugan [95] protocol. Tea type was chosen based on the results of de Siqueira et al. [130]. The virucide was used to inactive phage virions to avoid overestimation of phage-mediated bacterial killing (bactericidal activity) prior to 
plating. In separate experiments, this treatment was found not to affect bacterial viable counts (data not presented).

\subsection{Phage Surface Receptor Analysis}

Phage specificity to a particular bacterial receptor was tested on P. aeruginosa PAO1 mutants deficient in biosynthesis of flagella, type IV pili, alginate production, or structure of their lipopolysaccharide (LPS) was modified (Table S1), as previously described [124]. Bacterial susceptibility to phage was identified by spot testing ( $10 \mu \mathrm{L}$ volume) using a suspension of $10^{7} \mathrm{PFU} / \mathrm{mL}$. The plates were checked after $4-6 \mathrm{~h}$ and again after $18 \mathrm{~h}$ for the presence of a spot corresponding to confluent lysis located beneath applied volumes.

\subsection{Analysis of Virion Attachment Antagonism}

The impact of ciprofloxacin and colistin on phage virion attachment to bacterial surface was tested with a standard adsorption curve analysis [131]. In short, the PAO1 strain was mixed with PEV2 or LUZ19 phage at MOI 0.01 in MHBII with or without the presence of antibiotics, colistin, or ciprofloxacin (concertation range between $1 \times$ and $81 \times$ MIC). Immediately after mixing and further at $30 \mathrm{~s}$ intervals, $100 \mu \mathrm{L}$ aliquots were taken and mixed with $850 \mu \mathrm{L}$ of MHB supplemented with $50 \mu \mathrm{L}$ of chloroform. These mixtures were incubated for $10 \mathrm{~min}$ to kill any remaining phage-infected bacteria, centrifuged (10 min, $14,000 \mathrm{rpm}$ ) and phage titers were established from the supernatant by double agar layer method [128] to determine the amount of non-adsorbed or reversibly adsorbed phage.

\subsection{Phage Stability in the Presence of Antibiotics}

Phage stability in the presence of antibiotics was assessed by mixing phages PEV2, LUZ19 or $\Phi K M V\left(1 \times 10^{8} \mathrm{pfu} / \mathrm{mL}\right)$ and antibiotics, colistin or ciprofloxacin (concertation range between $1 \times$ and $81 \times \mathrm{MIC}$ ) in $1 \mathrm{~mL}$ of MHB. As a negative control, we used a mixture of phage and phage buffer or MHB. As a positive control, we used a mixture of phage and $0.1 \%$ SDS solution [132,133]. Samples were further incubated at $37^{\circ} \mathrm{C}$ for $24 \mathrm{~h}$ and subsequently phage titers were evaluated with the use of the standard double agar method [128].

\subsection{Analysis of Phage Infection Activity via Lysis Profiles}

Lysis profiles involve the addition of phages to relatively high densities of bacteria, with phage impact on bacteria observed as reductions in bacterial culture turbidity. To assure a robust measure of culture turbidity declines, i.e., as is generally assumed in these experiments to be associated with phage-induced bacterial lysis, cultures are not diluted following phage adsorption (contrast to one-step growth experiments, as described in the following section). The turbidity measurements were conducted at $\mathrm{OD}_{550 \mathrm{~nm}}$ with the use of SpectraMax i3x Multi-mode Microplate Reader (Molecular Devices, San Jose, CA, USA).

Phage, antibiotic, or both were added to log-phase P. aeruginosa PAO1 $\left(\mathrm{OD}_{600 \mathrm{~nm}}=0.32\right.$, $\sim 1.1 \times 10^{8} \mathrm{CFU} / \mathrm{mL}$; time, $\left.t=0 \mathrm{~min}\right)$. Subsequent incubations were at least $2 \mathrm{~h}$ in length and took place as $200 \mu \mathrm{L} /$ well volumes within 96 -well microtiter plates. For incubations, these plates were covered with Breathe-Easy Film (Diversified Biotech, Dedham, MA, USA) and kept at $37^{\circ} \mathrm{C}$. Turbidity measurements were taken every $5 \mathrm{~min}$ and cultures were shaken for $3 \mathrm{sec}$ before every read. All materials including microtiter plates were preincubated at experimental temperatures to limit physiological stress, and phages as well as antibiotics were prepared in MHB prior to use. Negative controls consisted of untreated PAO1 and MHB only. Input multiplicities of infection (MOIs) $[134,135]$ ranged from 0.1 (for virion production assessment) to 10 (for phage-induced bacteriolysis assessment). These MOIs corresponded to within-well titers of $\sim 1 \times 10^{7}, \sim 1 \times 10^{8}, \sim 5.0 \times 10^{8}$, and $1 \times 10^{9} \mathrm{PFU} / \mathrm{mL}$ (or MOIs of $0.1,1,5$, and 10, respectively). Following lysis profile determinations, PFU and CFU counts were assessed, initially via spot test assays, and for PFUs further via the double-layer method $[128,129]$. Experiments were performed in three technical repeats and three biological repeats. 


\subsection{Analysis of Phage Infection Activity via One-Step Growth}

One-step growth experiments were undertaken according to previously established methods [96-98,136], with modifications. A volume of $900 \mu \mathrm{L}$ of a mid-exponential bacterial culture (final concentration $\sim 2 \times 10^{8} \mathrm{CFU} / \mathrm{mL}$ ) in MHB was mixed with $100 \mu \mathrm{L}$ of PEV2 phage suspension (final concentration $\sim 1.0 \times 10^{6} \mathrm{PFU} / \mathrm{mL}$ ) to obtain an input MOI of 0.005 . Phages were allowed to adsorb for $8 \mathrm{~min}$ at $37^{\circ} \mathrm{C}$, after which time the mixture is diluted $10^{4}$-fold, with samples then taken at 20-30 s intervals for titer determination. $\mathrm{PFU} / \mathrm{mL}$ titers presented in the graphs are values from which unabsorbed phages values were subtracted. Antibiotic, if present, was added to PAO1 cultures $15 \mathrm{~min}$ prior to phage addition as well as to all dilution media. At least three biological repeats were performed.

\subsection{Statistics}

The area under the curve (AUC) was calculated by GraphPad Prism version 7.00 for Windows (GraphPad Software, La Jolla, CA, USA, www.graphpad.com, accessed on 15 October 2021) based on $5 \mathrm{~h}$ lysis profiles. Statistics were performed with a one-way ANOVA test. Statistical software R [137] was used for statistical computing and graphics based on $\log _{10}(\mathrm{AUC})$ values. Heat maps were plotted with pheatmap [138]. The pvclust [139] was used for assessing the uncertainty in hierarchical cluster analysis. For each cluster in hierarchical clustering, probability values ( $p$-values) are calculated via multiscale bootstrap resampling and ranging between 0 and 1 , which indicates how strong the cluster is supported by data. Two types of $p$-values are available: approximately unbiased (AU) $p$-value and bootstrap probability (BP) value. The AU $p$-value, which is calculated by multiscale bootstrap resampling, is a superior approximation to unbiased $p$-value over $\mathrm{BP}$ value computed by normal bootstrap resampling. With pvclust, hierarchical cluster analysis is performed via function hclust and automatically computes $p$-values for all clusters contained in the clustering of original data.

Supplementary Materials: The following are available online at https: / www.mdpi.com/article/ 10.3390/ph14111162/s1, Figure S1: Heat map analyses of PEV2 infection with colistin (A) and ciprofloxacin (B), Figure S2: High antagonism of colistin on LUZ19 infection activities, Figure S3: High antagonism of colistin on $\Phi K M V$ infection activities, Figure S4: Phage adsorption curves reveals high antagonism of colistin, Figure S5: Phage stability in the presence of colistin and ciprofloxacin, Figure S6: Low antagonism of ciprofloxacin on LUZ19 infection activities, Figure S7: Low antagonism of ciprofloxacin on $\Phi K M V$ infection activities, Table S1: Phage receptor identification using isogenic P. aeruginosa PAO1 surface mutants.

Author Contributions: K.M.D.-W. performed all experiments with help of A.C. (Alice Cai); A.C. (Anna Chen) and M.R.G. helped with optimization of one-step growth experiments; K.M.D.-W. and S.T.A. designed experiments and analyzed results; K.M.D.-W. and S.T.A. wrote the manuscript; D.J.W. and M.B.S. contributed to additional development of the manuscript. All authors have read and agreed to the published version of the manuscript.

Funding: Funding was provided by the Ohio State University President's Postdoctoral Scholars Program and Cystic Fibrosis Foundation C3 training award (Research Development Program, Grant MCCOY19RO, to K.M.D.-W.), a Gordon and Betty Moore Foundation Investigator Award (\#3790, to M.B.S.), and Public Health Service funding R01AI34895 (D.J.W.), R01AI43916 (D.J.W.), and R21AI156304 (S.T.A.).

Institutional Review Board Statement: Not applicable.

Informed Consent Statement: Not applicable.

Data Availability Statement: The data presented in this study are available in article.

Acknowledgments: We would like to thank Elizabeth Kutter and Rob Lavigne for providing phages that were used during this study. 
Conflicts of Interest: S.T.A. has consulted for and served on advisory boards for companies with phage therapy interests, holds an equity stake in a number of these companies, and maintains the websites phage.org and phage-therapy.org. No additional competing financial interest exist. The text presented represents the perspectives of the authors alone, and no outside help was received in its writing.

\section{Appendix A. Antibiotic MICs, Dosing, and Pharmacology}

\section{Appendix A.1. Colistin}

Colistin can be administrated parenterally, intravenously, or via inhalation. Currently there are no clear dosing guidelines, pharmacokinetics, or pharmacodynamics provided by the FDA. In Table A1 we present recommended dosing and target serum concentrations based on the most comprehensive study of colistin treatment of ill patients and recently published International Consensus Guidelines for the Optimal Use of Polymyxins [140].

Table A1. Colistin and ciprofloxacin pharmacology.

\begin{tabular}{|c|c|c|c|}
\hline Antibiotic & Dose & $\begin{array}{l}\text { Maximum Serum } \\
\text { Concentration }\end{array}$ & Area Under Curve (AUC) \\
\hline \multirow{2}{*}{$\begin{array}{c}\text { Colistin } \\
(\text { polymyxin E) * }\end{array}$} & $75-410 \mathrm{mg}^{2}$ & $0.48-9.38 \mu \mathrm{g} / \mathrm{mL}$ & N.D. \\
\hline & $\begin{array}{l}\text { 300-360 mg CBA for a patient } \\
\text { with normal renal function }{ }^{3}\end{array}$ & $\sim 2 \mu \mathrm{g} / \mathrm{mL}[140-142] *$ & $\sim 50 \mathrm{mg} \times \mathrm{h} / \mathrm{mL}^{* *}$ \\
\hline \multirow{4}{*}{ Ciprofloxacin ${ }^{1}$} & $250 \mathrm{mg}$ & $1.2 \mu \mathrm{g} / \mathrm{mL}$ & $4.8 \mu \mathrm{g} \times \mathrm{h} / \mathrm{mL}$ \\
\hline & $500 \mathrm{mg}$ & $2.4 \mu \mathrm{g} / \mathrm{mL}$ & $11.6 \mu \mathrm{g} \times \mathrm{h} / \mathrm{mL}$ \\
\hline & $750 \mathrm{mg}$ & $4.3 \mu \mathrm{g} / \mathrm{mL}$ & $20.2 \mu \mathrm{g} \times \mathrm{h} / \mathrm{mL}$ \\
\hline & $1000 \mathrm{mg}$ & $5.4 \mu \mathrm{g} / \mathrm{mL}$ & $30.8 \mu \mathrm{g} \times \mathrm{h} / \mathrm{mL}$ \\
\hline
\end{tabular}

${ }^{1}$ presented based on FDA dosing analysis and recommendations [143]. ${ }^{2}$ Garonzik et al. [141]. Their recommendations were against exceeding $300 \mathrm{mg}$ "colistin base activity" per day (about $5 \mathrm{mg} / \mathrm{kg} /$ day) for either the loading or maintenance doses. ${ }^{3}$ Based on International Consensus Guidelines for the Optimal Use of the Polymyxins: Endorsed by the American College of Clinical Pharmacy (ACCP), European Society of Clinical Microbiology and Infectious Diseases (ESCMID), Infectious Diseases Society of America (IDSA), International Society for Antiinfective Pharmacology (ISAP), Society of Critical Care Medicine (SCCM), and Society of Infectious Diseases Pharmacists (SIDP) [140]. CBA: colistin base activity. N.D.: not determined. * the target average steady-state total plasma colistin concentrations $\left(\mathrm{C}_{\mathrm{ss}, \text { avg }}\right)$ of $\geq 2.5 \mathrm{mg} / \mathrm{L}$ may increase the risk of nephrotoxicity (controversial in the field), which complicates the clinical decision to choose the appropriate colistin dosing [144-146]. ** maximum tolerable exposure.

Since there are no clear guidelines for colistin treatment, in our study we performed first a standard broth-based MIC analysis with the $P$. aeruginosa PAO1 reference strain $(1 \times \mathrm{MIC}=39.06 \mu \mathrm{M}=68.75 \mu \mathrm{g} / \mathrm{mL})$ and we employed the following concentrations in further experiments: $1 \times \mathrm{MIC}=39.06 \mu \mathrm{M}=68.75 \mu \mathrm{g} / \mathrm{mL}, 3 \times \mathrm{MIC}=117.18 \mu \mathrm{M}$ $=206.25 \mu \mathrm{g} / \mathrm{mL}, 9 \times \mathrm{MIC}=351.54 \mu \mathrm{M}=618.75 \mu \mathrm{g} / \mathrm{mL}, 20 \times \mathrm{MIC}=18.2 \mu \mathrm{M}=6.1 \mu \mathrm{g} / \mathrm{mL}$, $27 \times \mathrm{MIC}=24.70 \mu \mathrm{M}=8.24 \mu \mathrm{g} / \mathrm{mL}$, and $81 \times \mathrm{MIC}=74.10 \mu \mathrm{M}=24.72 \mu \mathrm{g} / \mathrm{mL}$.

\section{Appendix A.2. Ciprofloxacin}

In the clinic, ciprofloxacin is administrated in two forms, film-coated tablets-available in $100 \mathrm{mg}$, $250 \mathrm{mg}, 500 \mathrm{mg}$, and $750 \mathrm{mg}$ strengths-or oral suspension, available in 5\% (5 g ciprofloxacin in $100 \mathrm{~mL}$ ) and 10\% (10 g ciprofloxacin in $100 \mathrm{~mL})$ strengths [2]. Ciprofloxacin maximum serum concentrations and AUC in correlation to dose are presented in Table A1, as based on FDA directions for ciprofloxacin dosing and pharmacology [143].

For this study, a standard broth-based MIC analysis was performed, which indicated that ciprofloxacin inhibits macroscopically growth of sensitive P. aeruginosa PAO1 Krylov strain at $305.2 \mathrm{pg} / \mathrm{mL}(0.91 \mu \mathrm{M})$. Based on these results and FDA ciprofloxacin dose recommendations, we established concentrations span for further experiments as follows: $1 \times \mathrm{MIC}=0.91 \mu \mathrm{M}=303.2 \mathrm{ng} / \mathrm{mL}, 3 \times \mathrm{MIC}=2.74 \mu \mathrm{M}=909.5 \mathrm{ng} / \mathrm{mL}, 9 \times \mathrm{MIC}=8.23 \mu \mathrm{M}$ $=2.73 \mu \mathrm{g} / \mathrm{mL}, 20 \times \mathrm{MIC}=18.3 \mu \mathrm{M}=6.1 \mu \mathrm{g} / \mathrm{mL}, 27 \times \mathrm{MIC}=24.70 \mu \mathrm{M}=8.19 \mu \mathrm{g} / \mathrm{mL}$, and $81 \times \mathrm{MIC}=74.11 \mu \mathrm{M}=24.56 \mu \mathrm{g} / \mathrm{mL}$. 


\section{Appendix B. Interpretation of Lysis Profiles}

Phage infection characteristics can be inferred from lysis-profile experiments, with different aspects assessed given different starting (input) phage MOIs. These, as seen with phage PEV2 without antibiotic treatments, are summarized in Figure A1 and below. Specifically, MOIs of $0.1,1,5$, and 10 have been employed throughout this study, which can provide evidence of virion production, phage-induced bacterial lysis (i.e., lysis from within [80]), and phage lysis timing (latent period length), respectively.

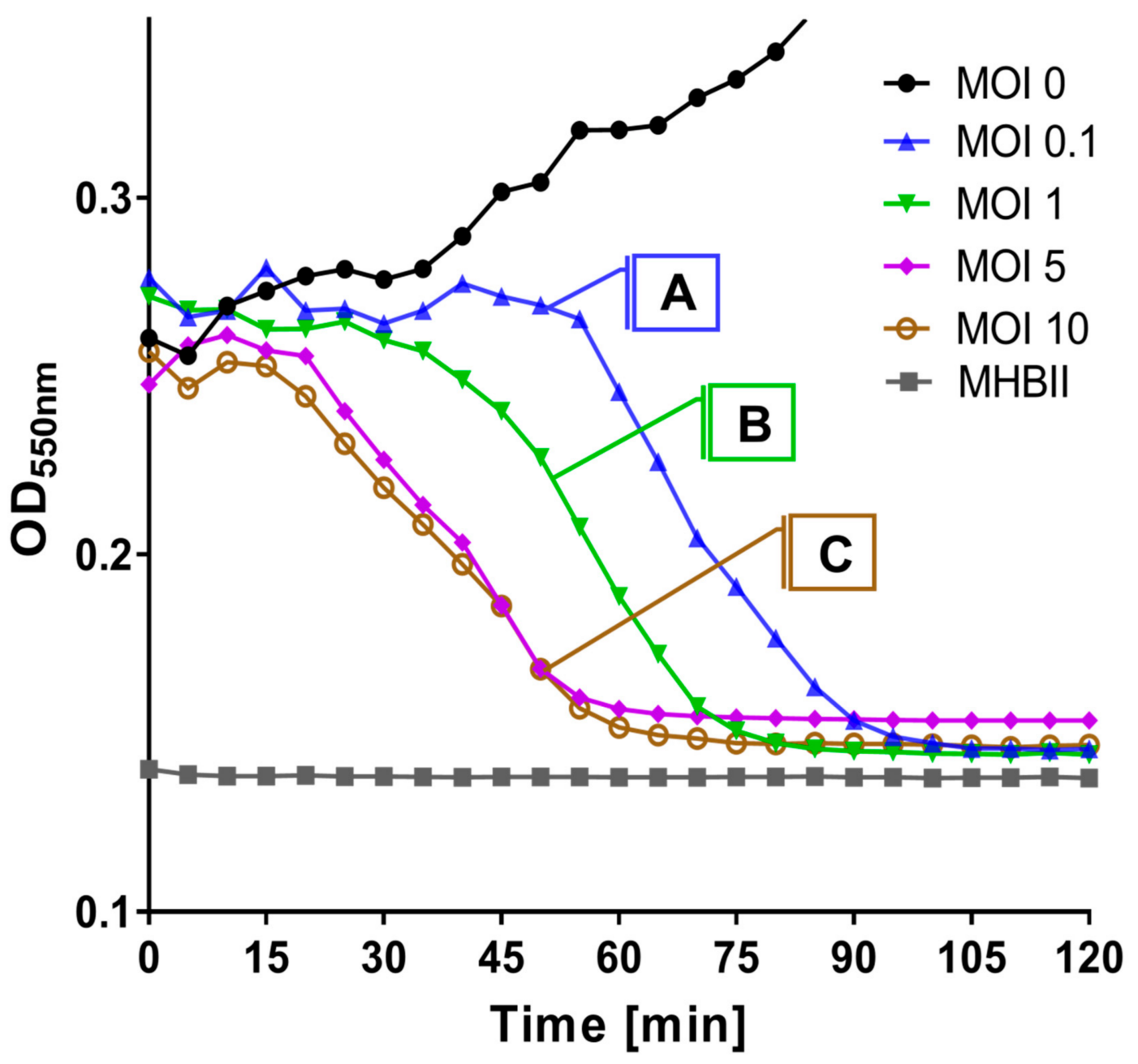

Figure A1. Phage PEV2 lysis profiles. (Curve A) Low starting MOI (=0.1): Phages must replicate and produce new virions to give rise to culture-wide bacterial lysis, as will occur after a minimum of 2 infection cycles. (Curve B) Intermediate MOI $(=1)$ : Culture-wide bacterial lysis is unlikely to be due to lysis from without (an extracellularly, enzymatically induced lysis of bacterial cells following high-multiplicity phage adsorptions), though lysis may be delayed relative to curve $C$ due to delayed and only fractional virion adsorption. (Curve C) High starting MOI (5 or 10): Timing of bacterial lysis should occur after a single phage latent period, unless somewhat sooner due to lysis from without. For especially MOIs 5 or 10, phage infections need only retain bacteriolytic activity to result in robust drops in turbidity.

\section{Appendix B.1. Curve A. Indicating Moderate or Greater Virion Production}

Starting with an input MOI of 0.1 , the timing of culture-wide lysis should begin after no less than two consecutive phage latent periods rather than after just one (curve A, Figure A1). This is because initially, at this MOI, only about $10 \%$ of the bacterial population can become phage infected, and it will take one latent period (the first latent period) before new virions are released. These new virions, if produced in sufficient numbers, can then adsorb and infect additional bacteria. Such 'two-step' growth can then result in relatively rapid culture-wide lysis, but only if phage burst sizes are sufficiently large 
to result in infection of the majority of bacteria present. That is, such as in excess of $\sim 10$ phages/infected bacterium so that most of the bacteria in the culture will have become phage infected after the first phage latent period. Observations of timely culture-wide reductions in turbidity at this low MOI thus can serve as an indication of phage virion production such as in the presence of antibiotic.

\section{Appendix B.2. Curve B. Indicating Lysis from Within}

With MOI 1 (curve B, Figure A1) we observe slower lysis than with MOIs 5 or 10 (curve C, Figure A1). This delay could be a consequence of slow initial phage adsorption to bacteria, as with an input MOI of 1 the rate that a bacterium becomes adsorbed by at least one phage virion should be up to five- to ten-fold slower than with the higher input MOIs. In addition, with MOI 1 only approximately one-half $\left[63 \%=100 \times\left(1-\mathrm{e}^{-1}\right)\right]$ of bacteria will be initially infected, i.e., as due to Poisson distributions of phage adsorption [126]. Slower culture-wide lysis at the end of phage latent periods given a starting MOI of 1 thereby can result both because fewer bacteria are infected and bacteria are infected more slowly relative to cultures initiated with MOIs of 5 or 10 . Notwithstanding such delays, culture-wide clearing for MOI 1 curves should be indicative of an occurrence of lysis from within as under these low-multiplicity conditions lysis from without (below) is unlikely.

\section{Appendix B.3. Curve C. Indicating Timing of Lysis}

The timing of lysis in lysis profiles, especially given starting MOIs of somewhat greater than 1 (here MOI 5 or 10), can approximate phage latent periods. This is seen here as the initial drop in turbidity observed soon after $15 \mathrm{~min}$ with the curves labeled as curve C in Figure A1. These higher input MOIs under certain circumstances, perhaps especially given antibiotic presence, might instead result from lysis from without. That is, a rapid, external digestion of cells walls and then bacterial lysis following high multiplicity virion adsorption [147]. Contrast instead lysis from within, which is phage-induced bacterial lysis as it normally occurs at the end of a phage's latent period [148], which with greater certainty is what is observed with given lower MOI experiments (curves A and B, Figure A1).

\section{Appendix C. Complications in Determining Ciprofloxacin Impact on Phages}

A handful of studies have evaluated the impact of $1 \times$ MIC or greater ciprofloxacin concentrations on the in vitro infection activities of various phages. These generally have been measured over many rounds of phage infection or with other issues that make it difficult to ascertain the impact of ciprofloxacin, at inhibiting concentrations, on phage infection activities. We review these studies as follows.

Valério et al. [149] observed an absence of an additional reduction in CFUs when Escherichia coli was treated in phosphate-buffered saline with phages (about $7 \times 10^{6} \mathrm{PFU} / \mathrm{mL}$ ) and $1 \times$ MIC $(0.5 \mu \mathrm{g} / \mathrm{mL})$ ciprofloxacin, vs. antibiotic alone. Without a carbon or energy source, however, our expectation is one of minimal phage replication. Furthermore, this is not a substantial starting titer of phages, and even though it represented a ratio of added phages to bacteria of 100 , densities of bacteria likely were insufficient $\left(<10^{5} \mathrm{CFU} / \mathrm{mL}\right)$ to support substantial additional phage population growth. Therefore, it is difficult to conclude whether or not ciprofloxacin in this case was inhibiting phage infection activities. MICs were determined using Mueller-Hinton agar.

Also with E. coli, Lopes et al. [150] observed less phage population growth in the presence of $1 \times$ MIC $(0.25 \mathrm{mg} / \mathrm{mL})$ ciprofloxacin than without, and no increases in phage numbers were seen at $2 \times \mathrm{MIC}(0.5 \mathrm{mg} / \mathrm{mL})$. These experiments were conducted in tryptic soy broth, however, while MICs were determined using MHB.

Alternatively, Jansen et al. [42] observed reductions in bacterial concentrations over antibiotic alone in the presence of an A. baumannii host and slightly over $1 \times$ MIC $(0.125 \mathrm{mg} / \mathrm{L})$ ciprofloxacin, with these experiments carried out in lysogeny broth. Bacterial growth was only slightly reduced in the presence of this amount of ciprofloxacin, however, with an 
endpoint $\mathrm{OD}_{590}$ in the absence of phages reduced from slightly more than 0.9 with no antibiotic to slightly less than 0.8 with $1 \times$ MIC. Roughly $0.5 \times$ MIC ciprofloxacin instead resulted in an endpoint $\mathrm{OD}_{590}$ of slightly more than 0.8 , also absent phages. The means of MIC determination does not appear to be reported.

Otherwise are studies carried out in biofilms, which can display greater tolerance to ciprofloxacin activity than broth-growing bacteria [123]. Thus, and just as with colistin (Section 3.1), ciprofloxacin concentrations that are found to be inhibitory of bacterial growth in broth may not be inhibitory to bacterial metabolic activities within biofilms. Working with P. aeruginosa PA14 biofilms, Chaudhry et al. [102] thus found that $1 \times$ MIC $(0.8 \mu \mathrm{g} / \mathrm{mL})$ ciprofloxacin did not block the production of new virions while $8 \times \mathrm{MIC}(6.4 \mu \mathrm{g} / \mathrm{mL}) \mathrm{did}$, though MIC was determined using planktonic rather than biofilm cultures. Indeed, $1 \times$ MIC ciprofloxacin alone had little impact on biofilm presence while $8 \times$ MIC ciprofloxacin acting alone had a substantial impact.

Similar results were seen by Dickey et al. [151] with Staphylococcus aureus biofilm in MHB and phage-ciprofloxacin co-treatment. Treatment with phage and ciprofloxacin at $2 \times$ MIC substantially reduced the number of biofilm-embedded bacteria, while ciprofloxacin alone also at $2 \times$ MIC did not reduce CFUs. When antibiotic concentration was increased to $10 \times$ MIC, CFUs were reduced, but there was no additional reduction with co-treatment with phages. This correlates with phage production in the presence of $2 \times$ MIC ciprofloxacin but no phage production in the presence of $10 \times$ MIC. It is uncertain what medium was used to determine MICs but this could have been MHB.

Verma et al. [152] saw no change in phage impact on Klebsiella pneumoniae biofilms with and without ciprofloxacin $(10 \mu \mathrm{g} / \mathrm{mL},>>1 \times \mathrm{MIC})$. As these twelve-hour biofilms appear to have not grown further in the presence of the antibiotic, their result is suggestive of a retention of phage anti-biofilm activity in the presence of ciprofloxacin. The phage used in that study, however, appeared to produce an anti-biofilm depolymerase enzyme, which could have reduced biofilm presence without corresponding phage infection activity, i.e., [153-158].

Luscher et al. [159] treated 6 h P. aeruginosa PAO1 infections of Calu-3 epithelial cell lines in minimal essential medium with phages in the presence of $16 \times$ MIC ciprofloxacin $(4.0 \mu \mathrm{g} / \mathrm{mL}$, which roughly corresponds to a maximum serum concentration of $750 \mathrm{mg}$ dose of ciprofloxacin in the clinic, $4.3 \mu \mathrm{g} / \mathrm{mL}$, and which corresponds to $14 \times$ MIC in our study). After $72 \mathrm{~h}$ post infection, they observed substantial bacteria-killing and multiple log increases in PFUs. Only a few PAO1 mutants were isolated following treatments, with all of these mutants' ciprofloxacin sensitive and all resistant to some or all phages. The time of treatment and these resistance results together are highly suggestive that at the start of treatments, which was six hours following epithelial cell infection with the bacteria, PAO1 cells were no longer in a planktonic state but instead had formed aggregates with biofilm-like properties. As with the biofilm studies discussed above, these bacteria therefore possibly exhibited increased tolerance to ciprofloxacin. In addition or alternatively, ciprofloxacin can positively diffuse and is taken up actively by Calu-3 epithelial cells $[160,161]$, possibly lowering effective ciprofloxacin concentrations. MICs were determined using MHB.

\section{References}

1. Schmidt, C. Phage therapy's latest makeover. Nat. Biotechnol. 2019, 37, 581-586. [CrossRef] [PubMed]

2. Lloyd, N.C.; Morgan, H.W.; Nicholson, B.K.; Ronimus, R.S. The composition of Ehrlich's salvarsan: Resolution of a century-old debate. Angew. Chem. Int. Ed. Engl. 2005, 44, 941-944. [CrossRef] [PubMed]

3. Riethmiller, S. From Atoxyl to Salvarsan: Searching for the magic bullet. Chemotherapy 2005, 51, 234-242. [CrossRef] [PubMed]

4. Domagk, G. Ein Beitrag zur Chemotherapie der bakteriellen Infektionen. Dtsch. Med. Wochenschr. 1935, 61, 250-253. [CrossRef]

5. Fleming, A. In-vitro tests of penicillin potency. Lancet 1942, 239, 732-733. [CrossRef]

6. Davies, J.; Davies, D. Origins and evolution of antibiotic resistance. Microbiol. Mol. Biol. Rev. 2010, 74, 417-433. [CrossRef]

7. Manyi-Loh, C.; Mamphweli, S.; Meyer, E.; Okoh, A. Antibiotic use in agriculture and its consequential resistance in environmental sources: Potential public health implications. Molecules 2018, 23, 795. [CrossRef] 
8. The Interagency Coordination Group on Antimicrobial Resistance (IACG). No Time to Wait-Securing the Future from DrugResistant Infections. 2019. Available online: https://www.who.int/docs/default-source/documents/no-time-to-wait-securingthe-future-from-drug-resistant-infections-en.pdfsfvrsn=5b424d7_6 (accessed on 15 October 2021).

9. CDC. Antibiotic Resistance Threats in the United States, 2019; U.S. Department of Health and Human Services, CDC: Atlanta, GA, USA, 2019.

10. de Kraker, M.E.; Stewardson, A.J.; Harbarth, S. Will 10 million people die a year due to antimicrobial resistance by 2050 ? PLoS Med. 2016, 13, e1002184. [CrossRef]

11. Bush, K. Alarming $\beta$-lactamase-mediated resistance in multidrug-resistant Enterobacteriaceae. Curr. Opin. Microbiol. 2010, 13, 558-564. [CrossRef]

12. Ceri, H.; Olson, M.E.; Stremick, C.; Read, R.R.; Morck, D.; Buret, A. The Calgary Biofilm Device: New technology for rapid determination of antibiotic susceptibilities of bacterial biofilms. J. Clin. Microbiol. 1999, 37, 1771-1776. [CrossRef]

13. Jolivet-Gougeon, A.; Bonnaure-Mallet, M. Biofilms as a mechanism of bacterial resistance. Drug Discov. Today Technol. 2014, 11, 49-56. [CrossRef]

14. Macia, M.D.; Rojo-Molinero, E.; Oliver, A. Antimicrobial susceptibility testing in biofilm-growing bacteria. Clin. Microbiol. Infect. 2014, 20, 981-990. [CrossRef]

15. Olsen, I. Biofilm-specific antibiotic tolerance and resistance. Eur. J. Clin. Microbiol. Infect. Dis. 2015, 34, 877-886. [CrossRef]

16. Brauner, A.; Fridman, O.; Gefen, O.; Balaban, N.Q. Distinguishing between resistance, tolerance and persistence to antibiotic treatment. Nat. Rev. Microbiol. 2016, 14, 320-330. [CrossRef]

17. Brauner, A.; Shoresh, N.; Fridman, O.; Balaban, N.Q. An experimental framework for quantifying bacterial tolerance. Biophys. J. 2017, 112, 2664-2671. [CrossRef]

18. Fisher, R.A.; Gollan, B.; Helaine, S. Persistent bacterial infections and persister cells. Nat. Rev. Microbiol. 2017, 15, 453-464. [CrossRef]

19. Górski, A.; Międzybrodzki, R.; Borysowski, J. Phage Therapy: A Practical Approach; Springer Nature: Cham, Switzerland, 2019.

20. Pirnay, J.P.; Kutter, E. Bacteriophages: It's a medicine, Jim, but not as we know it. Lancet Infect. Dis. 2021, 21, 309-311. [CrossRef]

21. Mushegian, A.R. Are there $10^{31}$ virus particles on Earth, or more, or less? J. Bacteriol. 2020, 202, e00052-20.

22. Jennes, S.; Merabishvili, M.; Soentjens, P.; Pang, K.W.; Rose, T.; Keersebilck, E.; Soete, O.; Francois, P.M.; Teodorescu, S.; Verween, G.; et al. Use of bacteriophages in the treatment of colistin-only-sensitive Pseudomonas aeruginosa septicaemia in a patient with acute kidney injury-a case report. Crit. Care 2017, 21, 129. [CrossRef]

23. Djebara, S.; Maussen, C.; De, V.D.; Merabishvili, M.; Damanet, B.; Pang, K.W.; De, L.P.; Strachinaru, I.; Soentjens, P.; Pirnay, J.P. Processing phage therapy requests in a Brussels military hospital: Lessons identified. Viruses 2019, 11, 265. [CrossRef]

24. Gabard, J.; Jault, P. How to achieve a good phage therapy clinical trial? In Phage Therapy: A Practical Approach; Górski, A., Międzybrodzki, R., Borysowski, J., Eds.; Springer: Berlin/Heidelberg, Germany, 2019; pp. 147-168.

25. Kincaid, R. Treatment and prevention of bacterial infections using bacteriophages: Perspectives on the renewed interest in the United States. In Phage Therapy: A Practical Approach; Górski, A., Międzybrodzki, R., Borysowski, J., Eds.; Springer: Berlin/Heidelberg, Germany, 2019; pp. 169-187.

26. Law, N.; Logan, C.; Yung, G.; Furr, C.L.L.; Lehman, S.M.; Morales, S.; Rosas, F.; Gaidamaka, A.; Bilinsky, I.; Grint, P. Successful adjunctive use of bacteriophage therapy for treatment of multidrug-resistant Pseudomonas aeruginosa infection in a cystic fibrosis patient. Infection 2019, 47, 665-668. [CrossRef]

27. McCallin, S.; Sacher, J.C.; Zheng, J.; Chan, B.K. Current state of compassionate phage therapy. Viruses 2019, 11, 343. [CrossRef]

28. Kutter, E.; De Vos, D.; Gvasalia, G.; Alavidze, Z.; Gogokhia, L.; Kuhl, S.; Abedon, S.T. Phage therapy in clinical practice: Treatment of human infections. Curr. Pharm. Biotechnol. 2010, 11, 69-86. [CrossRef] [PubMed]

29. Abedon, S.T.; Kuhl, S.J.; Blasdel, B.G.; Kutter, E.M. Phage treatment of human infections. Bacteriophage 2011, 1, 66-85. [CrossRef] [PubMed]

30. Reardon, S. Phage therapy gets revitalized. Nature 2014, 510, 15-16. [CrossRef] [PubMed]

31. Górski, A.; Międzybrodzki, R.; Łobocka, M.; Glowacka-Rutkowska, A.; Bednarek, A.; Borysowski, J.; Jónczyk-Matysiak, E.; Łusiak-Szelachowska, M.; Weber-Dabrowska, B.; Baginska, N.; et al. Phage therapy: What have we learned? Viruses 2018, 10, 288. [CrossRef] [PubMed]

32. Moelling, K.; Broecker, F.; Willy, C. A wake-up call: We need phage therapy now. Viruses 2018, 10, 688. [CrossRef] [PubMed]

33. Myelnikov, D. An alternative cure: The adoption and survival of bacteriophage therapy in the USSR, 1922-1955. J. Hist. Med. Allied Sci. 2018, 73, 385-411. [CrossRef]

34. Ślopek, S.; Weber-Dabrowska, B.; Dabrowski, M.; Kucharewicz-Krukowska, A. Results of bacteriophage treatment of suppurative bacterial infections in the years 1981-1986. Arch. Immunol. Ther. Exp. 1987, 35, 569-583.

35. Lu, T.K.; Collins, J.J. Engineered bacteriophage targeting gene networks as adjuvants for antibiotic therapy. Proc. Natl. Acad. Sci. USA 2009, 106, 4629-4634. [CrossRef]

36. Burrowes, B.; Harper, D.R.; Anderson, J.; McConville, M.; Enright, M.C. Bacteriophage therapy: Potential uses in the control of antibiotic-resistant pathogens. Exp. Rev. Anti-Infect. Ther. 2011, 9, 775-785. [CrossRef]

37. Schooley, R.T.; Biswas, B.; Gill, J.J.; Hernandez-Morales, A.; Lancaster, J.; Lessor, L.; Barr, J.J.; Reed, S.L.; Rohwer, F.; Benler, S.; et al. Development and use of personalized bacteriophage-based therapeutic cocktails to treat a patient with a disseminated resistant Acinetobacter baumannii infection. Antimicrob. Agents Chemother. 2017, 61, e00954-17. [CrossRef] 
38. Chan, B.K.; Turner, P.E.; Kim, S.; Mojibian, H.R.; Elefteriades, J.A.; Narayan, D. Phage treatment of an aortic graft infected with Pseudomonas aeruginosa. Evol. Med. Public Health 2018, 1, 60-66. [CrossRef]

39. Duplessis, C.; Biswas, B.; Hanisch, B.; Perkins, M.; Henry, M.; Quinones, J.; Wolfe, D.; Estrella, L.; Hamilton, T. Refractory Pseudomonas bacteremia in a 2-year-old sterilized by bacteriophage therapy. J. Pediatr. Infect. Dis. Soc. 2018, 7, 253-256. [CrossRef]

40. Ferry, T.; Boucher, F.; Fevre, C.; Perpoint, T.; Chateau, J.; Petitjean, C.; Josse, J.; Chidiac, C.; L'Hostis, G.; Leboucher, G.; et al. Innovations for the treatment of a complex bone and joint infection due to XDR Pseudomonas aeruginosa including local application of a selected cocktail of bacteriophages. J. Antimicrob. Chemother. 2018, 73, 2901-2903. [CrossRef]

41. Ferry, T.; Leboucher, G.; Fevre, C.; Herry, Y.; Conrad, A.; Josse, J.; Batailler, C.; Chidiac, C.; Medina, M.; Lustig, S.; et al. Salvage debridement, antibiotics and implant retention ("DAIR") with local injection of a selected cocktail of bacteriophages: Is it an option for an elderly patient with relapsing Staphylococcus aureus prosthetic-joint infection? Open Forum Infect. Dis. 2018, 5, ofy269. [CrossRef]

42. Jansen, M.; Wahida, A.; Latz, S.; Kruttgen, A.; Hafner, H.; Buhl, E.M.; Ritter, K.; Horz, H.P. Enhanced antibacterial effect of the novel T4-like bacteriophage KARL-1 in combination with antibiotics against multi-drug resistant Acinetobacter baumannii. Sci. Rep. 2018, 8, 14140. [CrossRef]

43. Kumaran, D.; Taha, M.; Yi, Q.; Ramirez-Arcos, S.; Diallo, J.S.; Carli, A.; Abdelbary, H. Does treatment order matter? Investigating the ability of bacteriophage to augment antibiotic activity against Staphylococcus aureus biofilms. Front. Microbiol. $2018,9,127$. [CrossRef]

44. LaVergne, S.; Hamilton, T.; Biswas, B.; Kumaraswamy, M.; Schooley, R.T.; Wooten, D. Phage therapy for a multidrug-resistant Acinetobacter baumannii craniectomy site infection. Open Forum Infect. Dis. 2018, 5, ofy064. [CrossRef]

45. Tkhilaishvili, T.; Lombardi, L.; Klatt, A.B.; Trampuz, A.; Di Luca, M. Bacteriophage Sb-1 enhances antibiotic activity against biofilm, degrades exopolysaccharide matrix and targets persisters of Staphylococcus aureus. Int. J. Antimicrob. Agents 2018, 52, 842-853. [CrossRef]

46. Yüksel, F.N.; Buzrul, S.; Akcelik, M.; Akcelik, N. Inhibition and eradication of Salmonella Typhimurium biofilm using P22 bacteriophage, EDTA and nisin. Biofouling 2018, 34, 1046-1054. [CrossRef]

47. Abedon, S.T. Phage-antibiotic combination treatments: Antagonistic impacts of antibiotics on the pharmacodynamics of phage therapy? Antibiotics 2019, 8, 182. [CrossRef]

48. Aslam, S.; Courtwright, A.M.; Koval, C.; Lehman, S.M.; Morales, S.; Furr, C.-L.L.; Rosas, F.; Brownstein, M.J.; Fackler, J.R.; Sisson, B.M.; et al. Early clinical experience of bacteriophage therapy in three lung transplant recipients. Am. J. Transplant. 2019, 19, 2631-2639. [CrossRef]

49. Aslam, S.; Pretorius, V.; Lehman, S.M.; Morales, S.; Schooley, R.T. Novel bacteriophage therapy for treatment of left ventricular assist device infection. J. Heart Lung Transplant. 2019, 38, 475-476. [CrossRef] [PubMed]

50. Dedrick, R.M.; Guerrero-Bustamante, C.A.; Garlena, R.A.; Russell, D.A.; Ford, K.; Harris, K.; Gilmour, K.C.; Soothill, J.; Jacobs-Sera, D.; Schooley, R.T.; et al. Engineered bacteriophages for treatment of a patient with a disseminated drug-resistant Mycobacterium abscessus. Nat. Med. 2019, 25, 730-733. [CrossRef] [PubMed]

51. Gilbey, T.; Ho, J.; Cooley, L.A.; Petrovic, F.A.; Iredell, J.R. Adjunctive bacteriophage therapy for prosthetic valve endocarditis due to Staphylococcus aureus. Med. J. Aust. 2019, 211, 142-143. [CrossRef] [PubMed]

52. Jault, P.; Leclerc, T.; Jennes, S.; Pirnay, J.P.; Que, Y.A.; Resch, G.; Rousseau, A.F.; Ravat, F.; Carsin, H.; Le, F.R.; et al. Efficacy and tolerability of a cocktail of bacteriophages to treat burn wounds infected by Pseudomonas aeruginosa (PhagoBurn): A randomised, controlled, double-blind phase 1/2 trial. Lancet Infect. Dis. 2019, 19, 35-45. [CrossRef]

53. Kuipers, S.; Ruth, M.M.; Mientjes, M.; de Sevaux, R.G.L.; van Ingen, J. A Dutch case report of successful treatment of chronic relapsing urinary tract infection with bacteriophages in a renal transplant patient. Antimicrob. Agents Chemother. 2019, 64, e01281-19. [CrossRef]

54. Maddocks, S.; Petrovic Fabijan, A.; Ho, J.; Lin, R.C.Y.; Ben Zakour, N.L.; Dugan, C.; Kliman, I.; Branston, S.; Morales, S.; Iredell, J.R. Bacteriophage therapy of ventilator-associated pneumonia and empyema caused by Pseudomonas aeruginosa. Am. J. Respir. Crit Care Med. 2019, 200, 1179-1181. [CrossRef]

55. Nir-Paz, R.; Gelman, D.; Khouri, A.; Sisson, B.M.; Fackler, J.; Alkalay-Oren, S.; Khalifa, L.; Rimon, A.; Yerushalmy, O.; Bader, R.; et al. Successful treatment of antibiotic resistant poly-microbial bone infection with bacteriophages and antibiotics combination. Clin. Infect. Dis. 2019, 69, 2015-2018. [CrossRef]

56. Onsea, J.; Soentjens, P.; Djebara, S.; Merabishvili, M.; Depypere, M.; Spriet, I.; De, M.P.; Debaveye, Y.; Nijs, S.; Vanderschot, P.; et al. Bacteriophage application for difficult-to-treat musculoskeletal infections: Development of a standardized multidisciplinary treatment protocol. Viruses 2019, 11, 891. [CrossRef]

57. Rogóż, P.; Amanatullah, D.F.; Międzybrodzki, R.; Manasherob, R.; Weber-Dąbrowska, B.; Fortuna, W.; Letkiewicz, S.; Górski, A. Phage therapy in orthopaedic implant-associated infections. In Phage Therapy: A Practical Approach; Górski, A., Międzybrodzki, R., Borysowski, J., Eds.; Springer: Berlin/Heidelberg, Germany, 2019; pp. 189-211.

58. Aslam, S.; Lampley, E.; Wooten, D.; Karris, M.; Benson, C.; Strathdee, S.; Schooley, R.T. Lessons learned from the first 10 consecutive cases of intravenous bacteriophage therapy to treat multidrug-resistant bacterial infections at a single center in the United States. Open Forum Infect. Dis. 2020, 7, ofaa389. [CrossRef] 
59. Bao, J.; Wu, N.; Zeng, Y.; Chen, L.; Li, L.; Yang, L.; Zhang, Y.; Guo, M.; Li, L.; Li, J.; et al. Non-active antibiotic and bacteriophage synergism to successfully treat recurrent urinary tract infection caused by extensively drug-resistant Klebsiella pneumoniae. Emerg. Microbes Infect. 2020, 9, 771-774. [CrossRef]

60. Doub, J.B.; Ng, V.Y.; Johnson, A.J.; Slomka, M.; Fackler, J.; Horne, B.; Brownstein, M.J.; Henry, M.; Malagon, F.; Biswas, B. Salvage bacteriophage therapy for a chronic MRSA prosthetic joint infection. Antibiotics 2020, 9, 241. [CrossRef]

61. Ferry, T.; Batailler, C.; Petitjean, C.; Chateau, J.; Fevre, C.; Forestier, E.; Brosset, S.; Leboucher, G.; Kolenda, C.; Laurent, F.; et al The potential innovative use of bacteriophages within the DAC ${ }^{\circledR}$ hydrogel to treat patients with knee megaprosthesis infection requiring "Debridement antibiotics and implant retention" and soft tissue coverage as salvage therapy. Front. Med. 2020, 7, 342. [CrossRef]

62. Gainey, A.B.; Burch, A.K.; Brownstein, M.J.; Brown, D.E.; Fackler, J.; Horne, B.; Biswas, B.; Bivens, B.N.; Malagon, F.; Daniels, R. Combining bacteriophages with cefiderocol and meropenem/vaborbactam to treat a pan-drug resistant Achromobacter species infection in a pediatric cystic fibrosis patient. Pediatr. Pulmonol. 2020, 55, 2990-2994. [CrossRef]

63. Petrovic Fabijan, P.; Lin, R.C.Y.; Ho, J.; Maddocks, S.; Ben Zakour, N.L.; Iredell, J.R. Westmead Bacteriophage Therapy Team Safety of bacteriophage therapy in severe Staphylococcus aureus infection. Nat. Microbiol. 2020, 5, 465-472. [CrossRef]

64. Rubalskii, E.; Ruemke, S.; Salmoukas, C.; Boyle, E.C.; Warnecke, G.; Tudorache, I.; Shrestha, M.; Schmitto, J.D.; Martens, A.; Rojas, S.V.; et al. Bacteriophage therapy for critical infections related to cardiothoracic surgery. Antibiotics 2020, 9, 232. [CrossRef]

65. Qin, J.; Wu, N.; Bao, J.; Shi, X.; Ou, H.; Ye, S.; Zhao, W.; Wei, Z.; Cai, J.; Li, L.; et al. Heterogeneous Klebsiella pneumoniae co-infections complicate personalized bacteriophage therapy. Front. Cell Infect. Microbiol. 2020, 10, 608402. [CrossRef]

66. Cano, E.J.; Caflisch, K.M.; Bollyky, P.L.; Van Belleghem, J.D.; Patel, R.; Fackler, J.; Brownstein, M.J.; Horne, B.; Biswas, B.; Henry, M.; et al. Phage therapy for limb-threatening prosthetic knee Klebsiella pneumoniae infection: Case report and in vitro characterization of anti-biofilm activity. Clin. Infect. Dis. 2021, 73, e144-e151. [CrossRef]

67. Dedrick, R.M.; Freeman, K.G.; Nguyen, J.A.; Bahadirli-Talbott, A.; Smith, B.E.; Wu, A.E.; Ong, A.S.; Lin, C.T.; Ruppel, L.C.; Parrish, N.M.; et al. Potent antibody-mediated neutralization limits bacteriophage treatment of a pulmonary Mycobacterium abscessus infection. Nat. Med. 2021, 27, 1357-1361. [CrossRef]

68. Doub, J.B.; Ng, V.Y.; Wilson, E.; Corsini, L.; Chan, B.K. Successful treatment of a recalcitrant Staphylococcus epidermidis prosthetic knee infection with intraoperative bacteriophage therapy. Pharmaceuticals 2021, 14, 231. [CrossRef]

69. Ferry, T.; Kolenda, C.; Batailler, C.; Gaillard, R.; Gustave, C.A.; Lustig, S.; Fevre, C.; Petitjean, C.; Leboucher, G.; Laurent, F. Case report: Arthroscopic "Debridement Antibiotics and Implant Retention" with local injection of personalized phage therapy to salvage a relapsing Pseudomonas aeruginosa prosthetic knee infection. Front. Med. 2021, 8, 569159. [CrossRef]

70. Lebeaux, D.; Merabishvili, M.; Caudron, E.; Lannoy, D.; Van Simaey, L.; Duyvejonck, H.; Guillemain, R.; Thumerelle, C.; Podglajen, I.; Compain, F.; et al. A case of phage therapy against pandrug-resistant Achromobacter xylosoxidans in a 12-year-old lung-transplanted cystic fibrosis patient. Viruses 2021, 13, 60. [CrossRef]

71. Ramirez-Sanchez, C.; Gonzales, F.; Buckley, M.; Biswas, B.; Henry, M.; Deschenes, M.V.; Horne, B.; Fackler, J.; Brownstein, M.J.; Schooley, R.T.; et al. Successful treatment of Staphylococcus aureus prosthetic joint infection with bacteriophage therapy. Viruses 2021, 13, 1182. [CrossRef]

72. Rostkowska, O.M.; Międzybrodzki, R.; Miszewska-Szyszkowska, D.; Górski, A.; Durlik, M. Treatment of recurrent urinary tract infections in a 60-year-old kidney transplant recipient. The use of phage therapy. Transpl. Infect. Dis. 2021, 23, e13391. [CrossRef]

73. Tan, X.; Chen, H.; Zhang, M.; Zhao, Y.; Jiang, Y.; Liu, X.; Huang, W.; Ma, Y. Clinical experience of personalized phage therapy against carbapenem-resistant Acinetobacter baumannii lung infection in a patient with chronic obstructive pulmonary disease. Front. Cell Infect. Microbiol. 2021, 11, 631585. [CrossRef]

74. Wu, N.; Dai, J.; Guo, M.; Li, J.; Zhou, X.; Li, F.; Gao, Y.; Qu, H.; Lu, H.; Jin, J.; et al. Pre-optimized phage therapy on secondary Acinetobacter baumannii infection in four critical COVID-19 patients. Emerg. Microbes Infect. 2021, 10, 612-618. [CrossRef]

75. Jawetz, E.; Gunnison, J.B.; Speck, R.S.; Coleman, V.R. Studies on antibiotic synergism and antagonism; the interference of chloramphenicol with the action of penicillin. AMA Arch. Intern. Med. 1951, 87, 349-359. [CrossRef]

76. Ocampo, P.S.; Lazar, V.; Papp, B.; Arnoldini, M.; Abel Zur, W.P.; Busa-Fekete, R.; Fekete, G.; Pal, C.; Ackermann, M.; Bonhoeffer, S. Antagonism between bacteriostatic and bactericidal antibiotics is prevalent. Antimicrob. Agents Chemother. 2014, 58, 4573-4582. [CrossRef]

77. Mueller, J.H.; Hinton, J. A protein-free medium for primary isolation of the Gonococcus and Meningococcus. Proc. Soc. Exp. Biol. Med. 1941, 48, 330-333. [CrossRef]

78. Reller, L.B.; Weinstein, M.; Jorgensen, J.H.; Ferraro, M.J. Antimicrobial susceptibility testing: A review of general principles and contemporary practices. Clin. Infect. Dis. 2009, 49, 1749-1755.

79. Patel, J.B. Performance Standards for Antimicrobial Susceptibility Testing; Clinical and Laboratory Standards Institute: Wayne, PA, USA, 2017.

80. Young, R. Bacteriophage lysis: Mechanisms and regulation. Microbiol. Rev. 1992, 56, 430-481. [CrossRef] [PubMed]

81. Ceyssens, P.J.; Brabban, A.; Rogge, L.; Lewis, M.S.; Pickard, D.; Goulding, D.; Dougan, G.; Noben, J.P.; Kropinski, A.; Kutter, E.; et al. Molecular and physiological analysis of three Pseudomonas aeruginosa phages belonging to the "N4-like viruses". Virology 2010, 405, 26-30. [CrossRef]

82. Sellick, K.M. Examination of Host Range of Pseudomonas aeruginosa Phages UT1, SN-T, and PEV2 for Treatment of Bacterial Biofilms in Fuels. Bachelor's Thesis, University of Dayton, Dayton, OH, USA, 2014. 
83. Lammens, E.; Ceyssens, P.J.; Voet, M.; Hertveldt, K.; Lavigne, R.; Volckaert, G. Representational Difference Analysis (RDA) of bacteriophage genomes. J. Microbiol. Meth. 2009, 77, 207-213. [CrossRef]

84. Lavigne, R.; Noben, J.P.; Hertveldt, K.; Ceyssens, P.J.; Briers, Y.; Dumont, D.; Roucourt, B.; Krylov, V.N.; Mesyanzhinov, V.V.; Robben, J.; et al. The structural proteome of Pseudomonas aeruginosa bacteriophage $\phi$ KMV. Microbiology 2006, 152, $529-534$. [CrossRef]

85. Biswas, S.; Brunel, J.M.; Dubus, J.C.; Reynaud-Gaubert, M.; Rolain, J.M. Colistin: An update on the antibiotic of the 21st century. Expert Rev. Anti-Infect. Ther. 2012, 10, 917-934. [CrossRef]

86. Hancock, R.E. Peptide antibiotics. Lancet 1997, 349, 418-422. [CrossRef]

87. Evans, M.E.; Feola, D.J.; Rapp, R.P. Polymyxin B sulfate and colistin: Old antibiotics for emerging multiresistant gram-negative bacteria. Ann. Pharmacother. 1999, 33, 960-967. [CrossRef]

88. Hermsen, E.D.; Sullivan, C.J.; Rotschafer, J.C. Polymyxins: Pharmacology, pharmacokinetics, pharmacodynamics, and clinical applications. Infect. Dis. Clin. N. Am. 2003, 17, 545-562. [CrossRef]

89. Tam, V.H.; Schilling, A.N.; Vo, G.; Kabbara, S.; Kwa, A.L.; Wiederhold, N.P.; Lewis, R.E. Pharmacodynamics of polymyxin B against Pseudomonas aeruginosa. Antimicrob. Agents Chemother. 2005, 49, 3624-3630. [CrossRef]

90. Johansen, H.K.; Moskowitz, S.M.; Ciofu, O.; Pressler, T.; Hoiby, N. Spread of colistin resistant non-mucoid Pseudomonas aeruginosa among chronically infected Danish cystic fibrosis patients. J. Cyst. Fibros. 2008, 7, 391-397. [CrossRef]

91. David, H.L.; Clavel, S.; Clement, F.; Moniz-Pereira, J. Effects of antituberculosis and antileprosy drugs on mycobacteriophage D29 growth. Antimicrob. Agents Chemother. 1980, 18, 357-359. [CrossRef]

92. Thai, T.; Salisbury, B.H.; Zito, P.M. Ciprofloxacin. 2021. Available online: https://pubmed.ncbi.nlm.nih.gov/30571075/ (accessed on 15 October 2021).

93. Drlica, K. Mechanism of fluoroquinolone action. Curr. Opin. Microbiol. 1999, 2, 504-508. [CrossRef]

94. Rawdon, E.J.; Dorier, J.; Racko, D.; Millett, K.C.; Stasiak, A. How topoisomerase IV can efficiently unknot and decatenate negatively supercoiled DNA molecules without causing their torsional relaxation. Nucleic Acids Res. 2016, 44, 4528-4538. [CrossRef]

95. Chibeu, A.; Balamurugan, S. Application of a virucidal agent to avoid overestimation of phage kill during phage decontamination assays on ready-to-eat meats. Meth. Mol. Biol. 2018, 1681, 97-105.

96. Ellis, E.L.; Delbrück, M. The growth of bacteriophage. J. Gen. Physiol. 1939, 22, 365-384. [CrossRef]

97. Hyman, P.; Abedon, S.T. Bacteriophage host range and bacterial resistance. Adv. Appl. Microbiol. 2010, 70, $217-248$.

98. Kropinski, A.M. Practical advice on the one-step growth curve. Meth. Mol. Biol. 2018, 1681, 41-47.

99. Xie, Y.; Wahab, L.; Gill, J.J. Development and validation of a microtiter plate-based assay for determination of bacteriophage host range and virulence. Viruses 2018, 10, 189. [CrossRef]

100. Pournaras, S.; Vrioni, G.; Neou, E.; Dendrinos, J.; Dimitroulia, E.; Poulou, A.; Tsakris, A. Activity of tigecycline alone and in combination with colistin and meropenem against Klebsiella pneumoniae carbapenemase (KPC)-producing Enterobacteriaceae strains by time-kill assay. Int. J. Antimicrob. Agents 2011, 37, 244-247. [CrossRef]

101. Ahmed, A.; Azim, A.; Gurjar, M.; Baronia, A.K. Current concepts in combination antibiotic therapy for critically ill patients. Indian J. Crit. Care Med. 2014, 18, 310-314.

102. Chaudhry, W.N.; Concepcion-Acevedo, J.; Park, T.; Andleeb, S.; Bull, J.J.; Levin, B.R. Synergy and order effects of antibiotics and phages in killing Pseudomonas aeruginosa biofilms. PLoS ONE 2017, 12, e0168615. [CrossRef] [PubMed]

103. Kollef, M.H. Inadequate antimicrobial treatment: An important determinant of outcome for hospitalized patients. Clin. Infect. Dis. 2000, 31 (Suppl. S4), S131-S138. [CrossRef]

104. Micek, S.T.; Lloyd, A.E.; Ritchie, D.J.; Reichley, R.M.; Fraser, V.J.; Kollef, M.H. Pseudomonas aeruginosa bloodstream infection: Importance of appropriate initial antimicrobial treatment. Antimicrob. Agents Chemother. 2005, 49, 1306-1311. [CrossRef] [PubMed]

105. Kumar, A.; Ellis, P.; Arabi, Y.; Roberts, D.; Light, B.; Parrillo, J.E.; Dodek, P.; Wood, G.; Kumar, A.; Simon, D.; et al. Initiation of inappropriate antimicrobial therapy results in a fivefold reduction of survival in human septic shock. Chest 2009, 136, 1237-1248. [CrossRef] [PubMed]

106. Bonhoeffer, S.; Lipsitch, M.; Levin, B.R. Evaluating treatment protocols to prevent resistance. Proc. Natl. Acad. Sci. USA 1997, 94, 12106-12111. [CrossRef]

107. Lee, J.; Patel, G.; Huprikar, S.; Calfee, D.P.; Jenkins, S.G. Decreased susceptibility to polymyxin B during treatment for carbapenemresistant Klebsiella pneumoniae infection. J. Clin. Microbiol. 2009, 47, 1611-1612. [CrossRef]

108. Fischbach, M.A. Combination therapies for combating antimicrobial resistance. Curr. Opin. Microbiol. 2011, 14, 519-523. [CrossRef]

109. Leekha, S.; Terrell, C.L.; Edson, R.S. General principles of antimicrobial therapy. Mayo Clin. Proc. 2011, 86, 156-167. [CrossRef]

110. REX Consortium Heterogeneity of selection and the evolution of resistance. Trends Ecol. Evol. 2013, 28, 110-118. [CrossRef]

111. Coulter, L.B.; McLean, R.J.; Rohde, R.E.; Aron, G.M. Effect of bacteriophage infection in combination with tobramycin on the emergence of resistance in Escherichia coli and Pseudomonas aeruginosa biofilms. Viruses 2014, 6, 3778-3786. [CrossRef]

112. Torres-Barceló, C.; Arias-Sanchez, F.I.; Vasse, M.; Ramsayer, J.; Kaltz, O.; Hochberg, M.E. A window of opportunity to control the bacterial pathogen Pseudomonas aeruginosa combining antibiotics and phages. PLoS ONE 2014, 9, e106628. [CrossRef]

113. Torres-Barceló, C.; Hochberg, M.E. Evolutionary rationale for phages as complements of antibiotics. Trends Microbiol. 2016, 24, 249-256. [CrossRef] 
114. Tagliaferri, T.L.; Jansen, M.; Horz, H.P. Fighting pathogenic bacteria on two fronts: Phages and antibiotics as combined strategy. Front. Cell Infect. Microbiol. 2019, 9, 22. [CrossRef]

115. Wiegand, I.; Hilpert, K.; Hancock, R.E. Agar and broth dilution methods to determine the minimal inhibitory concentration (MIC) of antimicrobial substances. Nat. Protoc. 2008, 3, 163-175. [CrossRef]

116. Chanishvili, N. A Literature Review of the Practical Application of Bacteriophage Research; Nova Publishers: Hauppauge, NY, USA, 2012.

117. Lin, Y.; Chang, R.Y.K.; Britton, W.J.; Morales, S.; Kutter, E.; Chan, H.K. Synergy of nebulized phage PEV20 and ciprofloxacin combination against Pseudomonas aeruginosa. Int. J. Pharm. 2018, 551, 158-165. [CrossRef]

118. Gordillo Altamirano, F.L.; Barr, J.J. Phage therapy in the postantibiotic era. Clin. Microbiol. Rev. 2019, 32, e00066-18. [CrossRef]

119. Lin, Y.; Chang, R.Y.K.; Britton, W.J.; Morales, S.; Kutter, E.; Li, J.; Chan, H.K. Inhalable combination powder formulations of phage and ciprofloxacin for P. aeruginosa respiratory infections. Eur. J. Pharm. Biopharm. 2019, 142, 543-552. [CrossRef]

120. Segall, A.M.; Roach, D.R.; Strathdee, S.A. Stronger together? Perspectives on phage-antibiotic synergy in clinical applications of phage therapy. Curr. Opin. Microbiol. 2019, 51, 46-50. [CrossRef]

121. Liu, G.C.; Green, S.I.; Min, L.; Clark, J.R.; Salazar, K.C.; Terwilliger, A.L.; Kaplan, H.B.; Trautner, B.W.; Ramig, R.F.; Maresso, A.W. Phage-antibiotic synergy is driven by a unique combination of antibacterial mechanism of action and stoichiometry. $m B i o$ 2020, 11, e01462-20.

122. Morrisette, T.; Kebriaei, R.; Lev, K.L.; Morales, S.; Rybak, M.J. Bacteriophage therapeutics: A primer for clinicians on phageantibiotic combinations. Pharmacotherapy 2020, 40, 153-168. [CrossRef]

123. Ciofu, O.; Tolker-Nielsen, T. Tolerance and resistance of Pseudomonas aeruginosa biofilms to antimicrobial agents-how P. aeruginosa can escape antibiotics. Front. Microbiol. 2019, 10, 913. [CrossRef] [PubMed]

124. Danis-Wlodarczyk, K.; Vandenheuvel, D.; Jang, H.B.; Briers, Y.; Olszak, T.; Arabski, M.; Wasik, S.; Drabik, M.; Higgins, G.; Tyrrell, J.; et al. A proposed integrated approach for the preclinical evaluation of phage therapy in Pseudomonas infections. Sci. Rep. 2016, 6, 28115. [CrossRef] [PubMed]

125. Oechslin, F.; Piccardi, P.; Mancini, S.; Gabard, J.; Moreillon, P.; Entenza, J.M.; Resch, G.; Que, Y.A. Synergistic interaction between phage therapy and antibiotics clears Pseudomonas aeruginosa infection in endocarditis and reduces virulence. J. Infect. Dis. 2017, 215, 703-712. [CrossRef] [PubMed]

126. Abedon, S.T.; Katsaounis, T.I. Basic phage mathematics. Meth. Mol. Biol. 2018, 1681, 3-30.

127. Danis-Wlodarczyk, K.; Olszak, T.; Arabski, M.; Wasik, S.; Majkowska-Skrobek, G.; Augustyniak, D.; Gula, G.; Briers, Y.; Jang, H.B.; Vandenheuvel, D.; et al. Characterization of the newly isolated lytic bacteriophages KTN6 and KT28 and their efficacy against Pseudomonas aeruginosa biofilm. PLoS ONE 2015, 10, e0127603.

128. Adams, M.H. Bacteriophages; InterScience: New York, NY, USA, 1959.

129. Kropinski, A.M.; Mazzocco, A.; Waddell, T.E.; Lingohr, E.; Johnson, R.P. Enumeration of bacteriophages by double agar overlay plaque assay. Meth. Mol. Biol. 2009, 501, 69-76.

130. de Siqueira, R.S.; Dodd, C.E.R.; Rees, C.E.D. Evaluation of the natural virucidal activity of teas for use in the phage amplification assay. Int. J. Food Microbiol. 2006, 111, 259-262. [CrossRef]

131. Ceyssens, P.J.; Lavigne, R.; Mattheus, W.; Chibeu, A.; Hertveldt, K.; Mast, J.; Robben, J.; Volckaert, G. Genomic analysis of Pseudomonas aeruginosa phages LKD16 and LKA1: Establishment of the $\phi K M V$ subgroup within the T7 supergroup. J. Bacteriol. 2006, 188, 6924-6931. [CrossRef]

132. Howett, M.K.; Neely, E.B.; Christensen, N.D.; Wigdahl, B.; Krebs, F.C.; Malamud, D.; Patrick, S.D.; Pickel, M.D.; Welsh, P.A.; Reed, C.A.; et al. A broad-spectrum microbicide with virucidal activity against sexually transmitted viruses. Antimicrob. Agents Chemother. 1999, 43, 314-321. [CrossRef]

133. Fister, S.; Robben, C.; Witte, A.K.; Schoder, D.; Wagner, M.; Rossmanith, P. Influence of environmental factors on phage-bacteria interaction and on the efficacy and infectivity of phage P100. Front. Microbiol. 2016, 7, 1152. [CrossRef]

134. Kasman, L.M.; Kasman, A.; Westwater, C.; Dolan, J.; Schmidt, M.G.; Norris, J.S. Overcoming the phage replication threshold: A mathematical model with implications for phage therapy. J. Virol. 2002, 76, 5557-5564. [CrossRef]

135. Abedon, S.T. Phage therapy dosing: The problem(s) with multiplicity of infection (MOI). Bacteriophage 2016, 6, e1220348. [CrossRef]

136. Pajunen, M.; Kiljunen, S.; Skurnik, M. Bacteriophage $\phi Y e O 3-12$, specific for Yersinia enterocolitica serotype O:3, is related to coliphages T3 and T7. J. Bacteriol. 2000, 182, 5114-5120. [CrossRef]

137. Global Biodiversity Information Facility. R: A Language and Environment for Statistical Computing. 2015. Available online: https:/ / www.gbif.org/tool/81287/r-a-language-and-environment-for-statistical-computing (accessed on 15 October 2021).

138. Kolde, R. Pheatmap: Pretty Heatmaps. 2021. Available online: https://cran.r-project.org/web/packages/pheatmap/index.html (accessed on 15 October 2021).

139. Suzuki, R.; Shimodaira, H. Pvclust: An R package for assessing the uncertainty in hierarchical clustering. Bioinformatics 2006, 22, 1540-1542. [CrossRef]

140. Tsuji, B.T.; Pogue, J.M.; Zavascki, A.P.; Paul, M.; Daikos, G.L.; Forrest, A.; Giacobbe, D.R.; Viscoli, C.; Giamarellou, H.; Karaiskos, I.; et al. International consensus guidelines for the optimal use of the polymyxins: Endorsed by the American College of Clinical Pharmacy (ACCP), European Society of Clinical Microbiology and Infectious Diseases (ESCMID), Infectious Diseases Society of America (IDSA), International Society for Anti-infective Pharmacology (ISAP), Society of Critical Care Medicine (SCCM), and Society of Infectious Diseases Pharmacists (SIDP). Pharmacotherapy 2019, 39, 10-39. 
141. Garonzik, S.M.; Li, J.; Thamlikitkul, V.; Paterson, D.L.; Shoham, S.; Jacob, J.; Silveira, F.P.; Forrest, A.; Nation, R.L. Population pharmacokinetics of colistin methanesulfonate and formed colistin in critically ill patients from a multicenter study provide dosing suggestions for various categories of patients. Antimicrob. Agents Chemother. 2011, 55, 3284-3294. [CrossRef]

142. Nation, R.L.; Garonzik, S.M.; Thamlikitkul, V.; Giamarellos-Bourboulis, E.J.; Forrest, A.; Paterson, D.L.; Li, J.; Silveira, F.P. Dosing guidance for intravenous colistin in critically-ill patients. Clin. Infect. Dis. 2017, 64, 565-571. [CrossRef]

143. Bayer Pharmaceuticals Corporation. CIPRO ${ }^{\circledR}$ (Ciprofloxacin Hydrochloride) TABLETS. 2004. Available online: https://www. fda.gov / files / drugs / published/Cipro--Approved-Dosing-for-Children-\%28label-approved-5-18-2005\%29.pdf (accessed on 15 October 2021).

144. Sorli, L.; Luque, S.; Grau, S.; Berenguer, N.; Segura, C.; Montero, M.M.; Alvarez-Lerma, F.; Knobel, H.; Benito, N.; Horcajada, J.P. Trough colistin plasma level is an independent risk factor for nephrotoxicity: A prospective observational cohort study. BMC Infect. Dis. 2013, 13, 380. [CrossRef]

145. Landersdorfer, C.B.; Nation, R.L. Colistin: How should it be dosed for the critically ill? Semin. Respir. Crit Care Med. 2015, 36, 126-135. [CrossRef] [PubMed]

146. Nation, R.L.; Li, J.; Cars, O.; Couet, W.; Dudley, M.N.; Kaye, K.S.; Mouton, J.W.; Paterson, D.L.; Tam, V.H.; Theuretzbacher, U.; et al. Framework for optimisation of the clinical use of colistin and polymyxin B: The Prato polymyxin consensus. Lancet Infect. Dis. 2015, 15, 225-234. [CrossRef]

147. Abedon, S.T. Lysis from without. Bacteriophage 2011, 1, 46-49. [CrossRef] [PubMed]

148. Cahill, J.; Young, R. Phage lysis: Multiple genes for multiple barriers. Adv. Virus Res. 2019, 103, 33-70.

149. Valério, N.; Oliveira, C.; Jesus, V.; Branco, T.; Pereira, C.; Moreirinha, C.; Almeida, A. Effects of single and combined use of bacteriophages and antibiotics to inactivate Escherichia coli. Virus Res. 2017, 240, 8-17. [CrossRef]

150. Lopes, A.; Pereira, C.; Almeida, A. Sequential combined effect of phages and antibiotics on the inactivation of Escherichia coli. Microorganisms 2018, 6, 125. [CrossRef]

151. Dickey, J.; Perrot, V. Adjunct phage treatment enhances the effectiveness of low antibiotic concentration against Staphylococcus aureus biofilms in vitro. PLoS ONE 2019, 14, e0209390. [CrossRef]

152. Verma, V.; Harjai, K.; Chhibber, S. Restricting ciprofloxacin-induced resistant variant formation in biofilm of Klebsiella pneumoniae B5055 by complementary bacteriophage treatment. J. Antimicrob. Chemother. 2009, 64, 1212-1218. [CrossRef]

153. Bartell, P.F.; Orr, T.E. Origin of polysaccharide depolymerase associated with bacteriophage infection. J. Virol. 1969, 3, 290-296. [CrossRef]

154. Hughes, K.A.; Sutherland, I.W.; Jones, M.V. Biofilm susceptibility to bacteriophage attack: The role of phage-borne polysaccharide depolymerase. Microbiology 1998, 144, 3039-3047. [CrossRef]

155. Azeredo, J.; Sutherland, I.W. The use of phages for the removal of infectious biofilms. Curr. Pharm. Biotechnol. 2008, 9, 261-266. [CrossRef] [PubMed]

156. Cornelissen, A.; Ceyssens, P.J.; T’Syen, J.; Van, P.H.; Noben, J.P.; Shaburova, O.V.; Krylov, V.N.; Volckaert, G.; Lavigne, R. The T7-related Pseudomonas putida phage $\varphi 15$ displays virion-associated biofilm degradation properties. PLoS ONE 2011, 6, e18597. [CrossRef]

157. Olszak, T.; Shneider, M.M.; Latka, A.; Maciejewska, B.; Browning, C.; Sycheva, L.V.; Cornelissen, A.; Danis-Wlodarczyk, K.; Senchenkova, S.N.; Shashkov, A.S.; et al. The O-specific polysaccharide lyase from the phage LKA1 tailspike reduces Pseudomonas virulence. Sci. Rep. 2017, 7, 16302. [CrossRef]

158. Knecht, L.E.; Veljkovic, M.; Fieseler, L. Diversity and function of phage encoded depolymerases. Front. Microbiol. 2020, 10, 2949. [CrossRef]

159. Luscher, A.; Simonin, J.; Falconnet, L.; Valot, B.; Hocquet, D.; Chanson, M.; Resch, G.; Kohler, T.; van Delden, C. Combined bacteriophage and antibiotic treatment prevents Pseudomonas aeruginosa infection of wild type and cftr- epithelial cells. Front. Microbiol. 2020, 11, 1947. [CrossRef]

160. Cavet, M.E.; West, M.; Simmons, N.L. Transepithelial transport of the fluoroquinolone ciprofloxacin by human airway epithelial Calu-3 cells. Antimicrob. Agents Chemother. 1997, 41, 2693-2698. [CrossRef]

161. Ong, H.X.; Traini, D.; Bebawy, M.; Young, P.M. Ciprofloxacin is actively transported across bronchial lung epithelial cells using a Calu-3 air interface cell model. Antimicrob. Agents Chemother. 2013, 57, 2535-2540. [CrossRef] 